$\begin{array}{r}\text { Bartın Üniversitesi } \\ \text { Eğitim Fakültesi Dergisi }\end{array}$
Cilt 6, Sayı 3, s. 1309-1330, Ekim 2017
BARTIN - TÜRKiYE $\begin{aligned} & \text { Bartin University } \\ & \text { Journal of Faculty of Education } \\ & \text { Volume 6, Issue 3, p. 1309-1330, 0ctober } 2017 \\ & \text { BARTIN - TURKEY }\end{aligned}$

\title{
Psikolojik Danışmanların Yabancılaşmaları Üzerinde Öz Yeterlik ve Tükenmişliğin Rolü
}

\begin{abstract}
Fatih CAMADAN, Yrd. Doç. Dr., Recep Tayyip Erdoğan Üniversitesi, Eğitim Fakültesi, fatih.camadan@erdogan.edu.tr, Orcid ID: 0000-0003-1516-4350
\end{abstract}

Betül ÇAYLAK, Milli Eğitim Bakanlı̆̆ı, betulcaylak@gmail.com, Orcid ID: 0000-0003-0900-5513

Okan YILMAZLAR, Milli Eğitim Bakanlığı, o.yilmazlar08@gmail.com, Orcid ID: 0000-0001-6202-7055

Kübra YILMAZ, Milli Eğitim Bakanlı̆ı, kubrayilmaz.9061@gmail.com, Orcid ID: 0000-0002-9454-2681

Selvin GÜL KARA, Milli Eğitim Bakanlığı, selvin_gul@hotmail.com, Orcid ID: 0000-0002-2321-4744

Öz: Bu araştırmanın amacı, psikolojik danışmanların yabancılaşmaları üzerinde öz yeterlik ve tükenmişliğin rolünün incelenmesidir. Araştırma 2016-2017 eğitim öğretim yılında Trabzon, Rize ve Artvin il ve ilçelerinde görev yapan toplam 203 psikolojik danışman ile gerçekleştirilmiştir. Katılımcıların 134 'ü kadın (\% 66.00) ve 69'u erkektir (\% 34.00). Araştırmanın sonucunda psikolojik danışmanların öz yeterlikleri ile yabancılaşmaları arasında orta düzeyde ve olumsuz yönde, tükenmişlikleri ile yabancılaşmaları arasında orta düzeyde olumlu yönde ve öz yeterlikleri ile tükenmişlikleri arasında orta düzeyde ve olumsuz yönde bir ilişki bulunmuştur. Öz yeterlik ve tükenmişliğinin birlikte yabancılaşma ile yüksek düzeyde olumlu yönde ilişkili olduğu ve değinilen değişkenlerin yabancılaşmanın \% 50'sini açıkladığı belirlenmiştir. Bağımsız değişkenlerin ikisinin de yabancılaşmayı anlamlı şekilde açıkladığı ancak tükenmişliğin daha güçlü bir yordayıcı olduğu anlaşılmıştır.

Anahtar Kelimeler: psikolojik danışman, yabancılaşma, öz yeterlik, tükenmişlik, psikolojik danışma ve rehberlik

\section{The Role of Self-Efficacy and Burnout on the Alienation of Psychological Counselors}

\begin{abstract}
The purpose of this research is to examine the role of self efficacy and burnout on the alienation of psychological counselors. The research was carried out with 203 psychological counselors working in the center and counties of Trabzon, Rize and Artvin in the academic year of 2016-2017o whom 134 (66.00\%) were female and 69 (34.00\%) were male. The results of the study indicated that there was a moderate and negative relationship between self efficacy and alienation, moderate and positive relationship between burnout and alienation, and moderate and negative relationship between self efficacy and burnout. The study revealed that self efficacy and burnout were positively correlated with alienation at a high level, and that self-efficacy and burnout explained $50 \%$ of alienation. Although self efficacy and burnout explained alienation in a meaningful way, burnout was found to be a stronger predictor.
\end{abstract}

Key Words: psychological counselor, alienation, self efficacy, burnout, psychological counseling and guidance 


\section{GiRiş}

Gelişen dünya, eğitim anlayışında da değişimler yaşatmıştır. Günümüzde bireylere sadece bilgi vermek yerine sağlıklı kişiliğe sahip nesiller yetiştirilmesi de amaçlanmaktadır. Bu gelişim ve değişimlerden hareketle, öğrencilere öğretim süreçlerinin yanı sıra rehberlik hizmetlerinin sunulması bir zorunluluk haline gelmiştir. Bu noktada rehberlik hizmetleri; öğrencilerin tüm gelişim alanlarını desteklemekte, ilerlemelerinin ve gelişimlerinin sürekliliği için yapacakları stratejik planlara katkı sağlayarak onlara cesaret vermektedir (Asarlı, 2012). Buna ek olarak bu hizmetler, kişinin ihtiyaç duyduğu yetenek, bilgi ve becerileri kazanmasını kolaylaştırmaktadır (Worzbyt vd., 2003).

Gerek yurtdışında gerekse Türkiye'de rehberlik hizmetlerinin önemi her geçen gün artmaktadır. Bu artışla beraber rehberlik hizmetlerinin yürütülmesinde belli sorunlar ortaya çıkmıştır. Moyer' in (2011) yapmış olduğu çalışmada psikolojik danışmanların (rehber öğretmen) iş yüklerinin fazla olması ve mesleki rollerinin yeterince belirgin olmamasından ötürü sorunlar yaşadıkları belirtilmiştir. Ayrıca bir psikolojik danışmana ilgilenebileceğinden fazla öğrencinin sorumluluğunun verilmesi de bir takım sorunlara neden olmaktadır. Psikolojik danışmanların bu gibi durumların üstesinden gelmelerinde yeterince destek alamamaları ise problemlerin önüne geçilmesini güçleştirmektedir. Avcı'ya (2010) göre rehberlik hizmetlerinde yaşanan sorunlar; planlamadaki hatalar, yeterli önemin verilmemesi, fiziki imkânların yetersizliği ve psikolojik danışmanların yaptığı ortak çalışmalarda yaşanan koordinasyon eksikliği olarak sıralanmıştır. Öztürk (2014) ise yaşanan sorunları rehberlik hizmetlerinde gerekli işbirliğinin sağlanamaması, okullardaki psikolojik danışman sayısının yeterli olmayışı, psikolojik danışmanın mesleki deneyimsizliği ve fiziki yetersizlikler olarak ifade etmiştir. Bunlara ek olarak diğer branş öğretmenlerinin rehberlik hizmetlerini sıkıcı bulmaları (Karataş ve Baltacı, 2013), gerekli malzemelerin eksikliği, yönetici ve öğretmenlerin rehberlikle ilgili bilgi ve deneyim eksikliği, rehberlik ders saatlerinin yetersizliği ve hizmetlerin işlevsizliği (Hatunoğlu ve Hatunoğlu, 2006) bu hizmetlerin yürütülmesinde ortaya çıkan diğer sorunlardır. Wachter'ın vd. (2008) yaptıkları araştırmanın sonucunda ise psikolojik danışmanların mesleki verimlilikleri için stresten arındırılmalarının ve stres oluşturabilecek durumlardan uzak tutulmalarının yararlı olacağı vurgulanmıştır. Yukarıda yer alan araştırma sonuçları değerlendirildiğinde yaşanan sorunların psikolojik danışmanları mesleğine karşı yabancılaştırabileceği düşünülmektedir. Bu bağlamda psikolojik danışmanların görevlerini en iyi şekilde yerine getirebilmeleri için problemlerin tespit edilmesi ve gerekli önlemlerin alınması açısından yabancılaşma davranışlarının incelenmesinin önemli olduğu düşünülmektedir. Bu düşünceden hareketle bu araştırmada psikolojik danışmanların yabancılaşmalarının daha iyi anlaşılabilmesi için öz yeterliğin ve tükenmişliğin bu davranış üzerindeki rolünün incelenmesi amaçlanmıştır.

Kişinin kendisiyle ve dünyayla olan karmaşık ilişki eksenine ışık tutan yabancılaşmanın anlaşılmasının günümüz insanının bir takım problemlerini aydınlatabileceği düşünülmektedir. Jaeggi'e (2014) göre yabancılaşma duyarsızlık ve içsel uzlaşmazlık, insanın kendine ve dış dünyaya karşı ilgisizlik ve ilişkisizlik durumudur. Bu bağlamda yabancılaşma kişinin kendisiyle veya dış dünyayla olan ilişkisinin kesilmesi değil, bir tür "ilişkisizlik ilişkisidir". Ayrıca yabancılaşan kişinin artık kendini aktif ve etkili bir özne değil pasif bir obje olarak görmeye başladığı ifade edilmiştir. Seeman (1959) yabancılaşmayı beş boyut altında toplamıştır. Bunlar; güçsüzlük, anlamsızlık, kuralsızlık, yalıtılmışık ve kendine yabancılaşmadır. Güçsüzlük; çalışanların yöneticiler tarafından karar verme haklarının kısıtlanması sonucunda, çalışma şartlarının kişiyi metaya indirgeyerek yozlaştırması, güçsüzleştirmesi ve kişiyi kişiye yabancılaştırmasıdır. Anlamsızık; şartlar kişinin karar vermesi için gerekli olan minimum netlik standartlarını karşılamadığında bireyin ne yapacağını ve neye inanacağını bilememesidir. Kuralsızık; bireyi düzenleyen sosyal normların artık kişi üzerindeki etkisinin zayıflamasıdır. 
Yalıtılmışlık; kişinin kültürel standartlardan uzaklaşması, topluma ve kültüre yabancılaşması ile kişinin toplumla olan bağlarındaki sıcaklığın, güvenin ve yoğunluğun azalmasıdır. Kendine yabancılaşma, bireyin kararlarını, beğenilerini ve değerlerini kendi karakteri yerine toplumun popüler tercihlerine dayandırmasıdır.

Yabancılaşma toplumsal hayattan iş hayatına kadar birçok alanda görülebilmektedir. Bu açıdan bireyler iş yaşamlarında da yabancılaşma yaşayabilmektedirler. Elma (2003) yabancılaşmayı kişinin işini anlamsız bulması, iş yerindeki ilişkilerinden haz alamaması, kendisini yalnız ve güçsüz hissetmesi; geleceğe dair beklentisini kaybetmesi ve kendisini çalıştığı yapının basit bir öğesi olarak görmesi şeklinde tanımlamıştır. Psikolojik danışmaların çalıştıkları kurumlarda problem yaşayan bireylere yardım ettikleri göz önünde bulundurulduğunda değinilen sorunu kendilerinin de yaşayıp yaşamadığı önemli bir durum olarak düşünülmektedir. Nitekim bu konuda yapılan bir araştırmada (Camadan vd., 2016); psikolojik danışmanların okul yönetimi, öğretmenler ve meslekleri ile ilgili konularda yabancılaşma yaşadıkları; bu duruma ilişkin getirilen çözüm önerilerinin ise psikolojik danışman kavramının açık olarak tanımlanması, görevlerinin net olarak belirlenmesi ve psikolojik danışmanların diğer öğretmenlerle etkili iletişim kurmaları yönünde olduğu anlaşılmıştır. Bu araştırma sonucuna dayalı olarak yabancılaşmanın psikolojik danışmanlar arasında da görülen bir durum olduğu anlaşılmaktadır. Ancak bu konuda yapılan araştırmaların değinilen çalışma ile sınırlı olduğu görülmüştür. Bu bağlamda psikolojik danışmanların yabancılaşma durumlarının incelenmesinin önemli olduğu düşünülmektedir.

Psikolojik danışmanların yabancılaşmalarını etkilediği düşünülen değişkenlerden birisi öz yeterliktir. Bandura'ya (1986) göre öz yeterlik bireylerin verecekleri tepkilere dair sahip oldukları yeteneklerine yönelik inançlarıdır. Bu inancın bireylerin kendilerini nasıl hissettiklerini, düşüncelerini, motivasyonlarını ve davranışlarını etkilediği ifade edilmiştir. Bireylerin öz yeterliklerinin gelişiminde yaşadıkları deneyimlerin olumlu ya da olumsuz yönde etkisi olduğu kabul edilmiştir. Ayrıca öz yeterliğin dört kaynaktan beslenerek geliştiğine değinilmiştir. Bunlar, bireyin kişisel deneyimleri, başkalarının deneyimleri ve bunları model alma, aldığı olumlu ya da olumsuz dönütler ve kişinin kendi yetkinliğini değerlendirme sürecindeki stresle baş etme durumudur. Işıksal ve Aşkar’a (2003) göre öz yeterlik bireyin tercihlerini, amaca ulaşmak için göstereceği çabayı ve bu süreçte yaşayacağı kaygıyı etkiler. Düşük öz yeterlik bireylere her şeyin olduğundan daha zor olduğunu düşündürmekte, stresle baş edebilmeyi ve problem çözmeyi zorlaştırmaktadır. Yüksek öz yeterlik ise problem çözme sürecinde ve zor aktivitelerle baş etmede bireylere dinginlik hissi kazandırmaktadır. Bu etkilerin sonucu olarak öz yeterlik bireylerin ulaşmak istedikleri seviyenin tahmin edeni ve karar vereni olarak ifade edilmiştir (Pajares, 1996). Dolayısıyla birey istenen davranışı gerçekleştirmede üstün bir yeteneğe sahip olmasa bile yapabileceğine olan inancı, onun bu davranışı yerine getirmek için çaba göstermesini sağlayabilir. Böylece birey karşısına çıkan olumsuzluklardan daha az etkilenerek sonuca ulaşmak için ısrarcı olabilir. Ya da birey istenen davranışı yerine getirme konusunda özel yeteneklere sahip olsa bile amaca ulaşacağına dair yeterli inancı yoksa gerekli çaba ve azmi göstermeyebilir.

Bireylerin öz yeterliklerinin gelişmesinde başkalarının da model alındığı bilinmektedir. $\mathrm{Bu}$ süreçte bireylerin yaşantısında etkisi olabilen modellerden birisi de psikolojik danışmanlardır. Zorlaşan hayat koşulları, sürekli değişen eğitim ve sınav sistemi günümüzde öğrencilerin hayata karşı daha kaygılı ve stresli olmasına sebebiyet verebilmektedir. Buna bağlı olarak bu sorunlarla baş etme sürecinde psikolojik danışmanlara büyük görev düşmektedir. Bu noktada öğrencilerin destek aldıkları psikolojik danışmanların öz yeterliklerinin de etkili olduğu düşünülmektedir. Psikolojik danışmanın öz yeterliği, Melchert vd. (1996) göre, danışanlarına karşı göstereceği performansı ve onlara fayda sağlayabileceğine dair inancı olarak 
tanımlanmıştır. Bu inancın gelişiminde psikolojik danışmanların, danışanlarının geri bildirimlerinden yola çıkarak kendi eylemlerini, düşüncelerini ve duygularını düzenlediği ifade edilmiştir (Larson ve Daniels, 1998). Bu sayede oluşan öz yeterlik inancı psikolojik danışmanların gelecekteki çalışmalarını da olumlu yönde etkileyebilmektedir. Bu konuyla ilgili literatür incelendiğinde psikolojik danışmanların öz yeterlikleri ile ilgili çeşitli çalışmaların yapıldığı görülmüştür. Bu araştırmalarda psikolojik danışmanların mesleki deneyimleri ile öz yeterlikleri arasında (Larson ve Daniels, 1998; Melchert vd., 1996; Owens vd., 2010) olumlu yönde anlamlı bir ilişkinin olduğu bulunmuştur. Erkan'ın (2011) yaptığı araştırmada psikolojik danışmanların öz yeterlikleri ile cinsiyet, yaş ve eğitim düzeyi arasında anlamlı bir ilişki bulunmazken, eğitim yaşantılarına ilişkin memnuniyetin öz yeterliği belirleyici güçlü bir etken olduğu ortaya çıkmıştır. Asarlı (2012), çalışmasında psikolojik danışmanların öz yeterliğinin, mezun olunan lisans programına, çalışılan okulun kademesine, okulun mevcuduna ve okulda çalışan psikolojik danışman sayısına göre değişiklik göstermediği; bunun yanı sıra okullarda üç ve üzeri dönem staj yapanların uygulama yapmayanlara veya bir dönem uygulama yapanlara göre öz yeterliklerinin anlamlı derecede daha yüksek olduğu bulunmuştur. 11 yıl ve üzerinde çalışanların öz yeterliklerinin de 0-5 yıl çalışanlardan daha yüksek olduğu saptanmıştır. Bilgiç (2011), araştırmasında, lisansüstü eğitim alan ve deneyimli psikolojik danışmanların öz yeterliklerinin diğerlerine göre oldukça yüksek olduğu sonucuna ulaşmıştır. Ayrıca cinsiyet ve görev yeri açısından öz yeterliklerinin anlamlı şekilde farklılık göstermediği bulunmuştur. Gündüz ve Çelikkaleli'nin (2009) yaptıkları araştırmada psikolojik danışmanlardan erkek olan ve mesleki tecrübesi fazla olanların öz yeterliklerinin daha yüksek olduğu belirlenmiştir. Bununla birlikte okul idarecilerinden destek alanların almayanlara göre daha yüksek öz yeterliğe sahip olduğu ortaya koyulmuştur. Ayrıca görev yapılan okul türüne göre ise öz yeterlikleri açısından anlamlı bir farklılık görülmemiştir. Aksoy ve Diken (2009) araştırmalarında psikolojik danışmanların özel eğitime ilişkin öz yeterliklerinin cinsiyetlerine ve yaşlarına göre bir farklılık göstermediği; bunun yanında mesleki deneyimi fazla olanların öz yeterliklerinin daha yüksek olduğu sonucuna ulaşmışlardır.

Psikolojik danışmanların yabancılaşmalarını etkilediği düşünülen değişkenlerden bir diğeri de tükenmişliktir. İnsanların çalıştıkları işleriyle kurdukları ilişki ve bu ilişkide bir sorun meydana geldiğinde oluşabilecek olan problemler, modern çağın önemli bir olgusu olarak değerlendirilmektedir. Bu olgu için kullanılan tükenmişlik terimi, 1970'li yıllarda Amerika'da, özellikle hizmet sektöründe dikkate alınmaya başlanmıştır. Tükenmişlik; genel olarak kişinin bıkkınlık içerisinde olması, işine duyduğu bağlıık ve idealizmini kaybetmesi şeklinde ifade edilmiştir (Maslach vd., 2001). Dolayısıyla tükenmişliğin bilimsel araştırmaların konusu olmadan önce zaten bunu yaşayanlar tarafından önemli bir sosyal problem olarak algılandığı anlaşılmaktadır. Bu yüzden bu kavramın bilimsel teoriler veya deneysel çalışmalar sonucunda ortaya çıkmadığı ve kişilerin iş hayatında yaşadıkları problemlere dayandığı ifade edilmiştir (Maslach, 1982).

Tükenmişliğin standart olarak kabul edilebilecek tek bir tanımı bulunmamaktadır. Freudenberger (1974) tükenmişliği; kişinin başarısındaki azalma, kendisini yeterince enerjik ve güçlü hissetmemesi veya isteklerinin yerine gelmemesi sonucu kendisini içsel olarak tükenmiş hissetmesi şeklinde tanımlamıştır. Maslach'a (1982) göre tükenmişlik; kişinin iş ortamında sürekli karşılaştığı insanlara karşı duyarsızlaşması, duygusal olarak çöküntü yaşaması ve öz yeterliğinde azalma olarak görülen bir problemdir. Ayrıca bedensel bitkinlik, kendini sürekli yorgun hissetme, olaylar karşısında çaresizlik ve ümitsizlik gibi fiziksel, zihinsel ve duygusal boyutları olan bir problem olduğundan bahsetmiş̧ir. Maslach ve Goldberg (1998) ise tükenmişliği; duygusal tükenme, duyarsızlaşma ve kişisel başarıda düşme şeklinde boyutlandırarak ele almışlardır. Duygusal tükenmede bireyde yorgunluk, enerji eksikliği ve duygusal olarak yıpranmış hissetme gibi belirtiler görülmektedir. Duyarsızlaşma bireylerin 
etkileşimde bulundukları kişilere ve çalıştıkları örgüte karşı mesafeli, kayıtsız ve küçümseyici bir tavır takınmaları ile ilgilidir. Kişisel başarıda düşmede ise kişi kendisinin yetersiz olduğunu düşünmekte ve motivasyonunda azalma yaşamaktadır.

Psikolojik danışmanlar eğitim kurumlarında yöneticiler, öğretmenler, öğrenciler ve aileler olmak üzere tüm paydaşlarla yoğun etkileşim halindedirler. Bu durum ise yorucu bir süreç olduğundan psikolojik danışmanların tükenmişlik yaşama ihtimalleri söz konusudur. Psikolojik danışmanların yaşadığı tükenmişliği konu edinen birçok araştırmaya rastlanmıştır. Bu araştırmalardan Umay (2015) psikolojik danışmanların, tükenmişliğin genelini ve duyarsızlaşma, duygusal tükenme, kişisel başarı duygusunda azalma alt boyutlarını yaşadıkları sonuçlarına ulaşmıştır. Stickel (1991) psikolojik danışmanların orta seviyede duygusal tükenme ve duyarsızlaşma; düşük seviyede kişisel başarıda düşme hissi yaşadığını saptamıştır. Belgi (2016) ise psikolojik danışmanların tükenmişliklerinin düşük düzeyde olduğu sonucuna ulaşmıştır. Tükenmişliğin nedenlerinin incelendiği araştırmalarda Bardhoshi'ye vd. (2014) göre psikolojik danışmanların, psikolojik danışmanlık dışında işlerle görevlendirilmesinin tükenmişlik yaşamalarına sebep olduğu belirlenmiştir. Wachter vd. (2008) tarafından yapılan araştırmada psikolojik danışmanların öz saygıları ve kendilerini algılayış biçimlerinin tükenmişliklerini olumlu yönde açıkladığı sonucuna varılmıştır. Butler'in (2005) yaptığı araştırmada ise psikolojik danışmanların benlik saygıları ile tükenmişlikleri arasında olumsuz yönde bir ilişkinin olduğu ortaya koyulmuştur. Bazı araştırmalarda ise psikolojik danışmanların tükenmişlikleri çeşitli demografik değişkenler açısından incelenmiştir. Bu araştırmalardan Başören'in (2005) araştırmasında psikolojik danışmanların cinsiyetlerine göre tükenmişlikleri arasında anlamlı bir farklılık olmadığı; Akten (2007) ve Yıldız (2012) tarafından yapılan araştırmalarda ise duygusal tükenmişliğin bayan psikolojik danışmanlarda daha yüksek olduğu saptanmıştır. Görev yapılan öğretim basamağı değişkeninin ele alındığı araştırmalarda tükenmişliğin öğretim basamağına göre farklılık göstermediği görülmüştür (Başören, 2005; Çınar, 2016). Bununla birlikte bazı araştırmalarda görev yapılan öğretim basamağı değişkeninin psikolojik danışmanlarda tükenmişliğin duyarsızlaşma boyutunda etkili olduğu, kişisel başarısızlık ve duygusal tükenme boyutlarında etkili olmadığı (Akten, 2007); ilköğretimde çalışan psikolojik danışmanların duyarsızlaşma boyutunda, ortaöğretim ve rehberlik araştırma merkezinde çalışanların ise kişisel başarısızlık boyutunda daha fazla tükenmişlik yaşadıkları (Kaya, 2009); ilköğretim basamağında görev yapan psikolojik danışmanların ortaöğretimdekilere göre ve ortaöğretimdekiler ise rehberlik araştırma merkezindekilere göre daha fazla duygusal tükenmişlik yaşadıkları (ikiz, 2010) ortaya koyulmuştur. Tükenmişliğin yaş değişkeni açısından incelendiği bazı araştırmalarda psikolojik danışmanların tükenmişliklerinin yaşa göre değişmediği (Aydemir, 2014; Çınar, 2016; ikiz, 2010; Yıldız, 2012) bulunurken; Kaya, (2009) tarafından yapılan araştırmada 31-40 yaş arasında yer alan psikolojik danışmanların diğer yaştakilere göre daha az tükenmişlik yaşadıkları ortaya koyulmuştur. Butler'in (2005) yaptığı araştırmada ise, hizmet yılı fazla olan psikolojik danışmanların tükenmişliklerinin daha fazla olduğu sonucuna ulaşılmıştır.

Yukarıdaki açıklamalardan hareketle çalışanların kurumlarında yabancılaşma yaşayabildikleri ve bunun da bireylerin performansını olumsuz yönde etkileyen bir durum olduğu anlaşılmaktadır. İlgili literatürde yabancılaşmanın psikolojik danışmanlar arasında da görüldüğünü ortaya koyan çalışmalara rastlanmıştır. Dolayısıyla psikolojik danışmanların yaşadıkları bu durumun ayrıntılı şekilde ele alınmasının ve nedenlerinin belirlenmesinin önemli olduğu düşünülmüştür. İlgili alan yazın taramalarında bireylerin iş performansları üzerinde öz yeterlik ve tükenmişliğin de etkili olduğu görülmüştür. Bu bağlamda değinilen değişkenlerin yabancılaşma üzerinde de etkisinin olabileceği tahmin edilmiştir. Bu konuda yapılan araştırmalar incelendiğinde yabancılaşma, öz yeterlik ve tükenmişliğin beraber ele alınarak incelendiği herhangi bir çalışmaya rastlanmamıştır. Dolayısıyla yapılan bu araştırmanın bu 
yönüyle alan yazına katkı sağlayacağı değerlendirilmiştir. Ayrıca psikolojik danışmanların yabancılaşmalarına ilişkin elde edilecek sonuçların, psikolojik danışmanların iş hayatlarına yönelik yapılacak geliştirme ve iyileştirmelerle ilgili çalışmalara fikir vereceği öngörülmüştür. Bununla birlikte yapılan çalışmalarda bu araştırmanın değişkenlerinin yaş, cinsiyet, eğitim düzeyi, görev yapılan okul türü ve görev yapılan öğretim basamağı gibi çeşitli demografik değişkenler açısından farklılaşıp farklılaşmadığının incelendiği görülmüştür. Bu araştırma kapsamında da araştırmanın değişkenlerinin yaygın olarak araştırılmaya değer görülen cinsiyet, görev yapılan öğretim basamağı (ilkokul, ortaokul ve lise) ve yaş değişkenleri açısından farklılaşma durumunun incelenmesinin önemli olduğu düşünülmüştür. Bu açıklamalar kapsamında araştırmanın amacı, psikolojik danışmanların yabancılaşmaları üzerinde öz yeterlik ve tükenmişliğin rolünün incelenmesi olarak belirlenmiş olup aşağıdaki sorulara cevap aranmıştır:

1. Psikolojik danışmanların öz yeterlik ve tükenmişlikleri yabancılaşmalarını yordamakta mıdır?

2. Psikolojik danışmanların yabancılaşma, öz yeterlik ve tükenmişlikleri cinsiyet, görev yapılan öğretim basamağı (ilkokul, ortaokul ve lise) ve yaş değişkenlerine göre anlamlı şekilde farklılaşmakta mıdır?

\section{YÖNTEM}

Bu bölümde araştırmanın modeli, çalışma grubu, ölçme araçları, verilerin toplanması ve verilerin analizi ile ilgili bilgilere yer verilmiştir.

\subsection{Model}

Nicel araştırma yaklaşımı çerçevesinde gerçekleştirilen bu araştırmanın modeli ilişkisel taramadır. illişkisel tarama modellerinde çözümlemeler korelasyon türü ve karşılaştırma türünde yapılabilmektedir (Karasar, 2016). Bu araştırmada değinilen iki tarama modeli kullanılmıştır. Bu kapsamda araştırmada psikolojik danışmanların yabancılaşma, öz yeterlik ve tükenmişlikleri arasındaki ilişkiler incelenmiştir. Ayrıca psikolojik danışmanların yabancılaşma, öz yeterlik ve tükenmişlikleri cinsiyet, görev yapılan öğretim basamağı ve yaş açısından karşılaştırılmıştır.

\section{2. Çalışma Grubu}

Araştırma 2016-2017 eğitim öğretim yılında Trabzon, Rize ve Artvin il ve ilçelerinde görev yapan toplam 203 psikolojik danışman ile gerçekleştirilmiştir. Katılımcıların 134'ü kadın (\% 66.00) ve 69'u erkektir (\% 34.00). Ayrıca 65'inin ilkokulda (\% 32.00), 73'ünün ortaokulda (\% 36.00 ) ve $65^{\prime}$ inin lisede (\% 32.00) görev yaptıkları belirlenmiştir. Bununla birlikte 51'i $22-24$ (\% 25.10), 64'ü 25-27 (\% 31.50), 44'ü 28-32 (\% 21.70) ve 44'ü 33-54 (\% 21.70) yaş aralığındadır.

\section{3. Ölçme Araçları}

Bu araştırma kapsamında verilerin toplanmasında Okul Psikolojik Danışmanı ÖzYeterlik Ölçeği, Tükenmişlik Ölçeği Kısa Formu, Yabancılaşma Ölçeği ve Kişisel Bilgi Formu kullanılmıştır. Değinilen ölçme araçlarına ilişkin bilgiler aşağıda sunulmuştur.

\subsubsection{Okul Psikolojik Danışmanı Öz-Yeterlik Ölçeği}

Bodenhorn ve Skaggs (2005) tarafından geliştirilen ve Erkan Atik (2011) tarafından Türkçe'ye uyarlanan bu ölçek Likert tipinde beşli derecelendirmeli olup bireylerin okul psikolojik danışmanı olarak mevcut yeteneklerine ilişkin yeterlik inançlarını "1=Hiç Güvenmiyorum" dan " $5=$ Çok Güveniyorum" a kadar puanlamalarına dayalıdır. 43 maddeden oluşan ölçek Kişisel ve Sosyal Gelişim, Öncülük Etme ve Değerlendirme, Kariyer Gelişimi ve Akademik Gelişim, İşbirliği ve Kültürel Kabul olmak üzere beş boyutlu olup toplam puan 
hesaplanarak da kullanılabilmektedir. Ölçekten alınan puanların yükselmesi bireylerin öz yeterlik inançlarının da arttığı anlamına gelmektedir. Ölçeğin geçerliğine ilişkin yapılan açımlayıcı faktör analizi sonucunda beş boyutlu yapının toplam varyansın $\% 55.86$ 'sını açıkladığı bulunmuştur. Ayrıca maddelerin faktör yüklerinin .40 ile .72 arasında değiştiği saptanmıştır. Yapılan doğrulayıcı faktör analizi sonucuna göre de ölçeğin 5 boyutlu yapısının doğrulandığı anlaşılmıştır. Ölçeğin güvenirliğine ilişkin hesaplanan Cronbach alfa iç tutarlılık katsayısının; alt boyutlar için .88 ile .74 arasında değiştiği ve ölçeğin toplamı için: .96 olduğu bulunmuştur. Bu sonuçlara dayalı olarak ölçeğin geçerlik ve güvenirliğinin sağlandığı değerlendirilmiştir. Ölçme aracının bu araştırma için geçerli ve güvenilir olup olmadığı kontrol edilmiştir. Ölçeğin geçerliği için doğrulayıcı faktör analizi yapılmıştır. Ulaşılan uyum iyiliği değerlerinin $\left(\chi^{2} / d f=3.07\right.$, $\mathrm{GFI}=0.91, \mathrm{CFI}=, .90, \mathrm{RMSEA}=0.07, \mathrm{SRMR}=0.08$ ) kabul edilebilir düzeyde olduğu görülmüştür (Tabachnick ve Fidell, 2015). Ölçeğin güvenirliği için hesaplanan Cronbach alfa iç tutarlılık katsayısının ölçeğin toplamı için: .87 olduğu belirlenmiştir.

\subsubsection{Tükenmişlik Ölçeği Kısa Formu}

Pines (2005) tarafından geliştirilen ve Çapri'nin (2013) Türkçeye uyarladığı bu ölçek kişilerin mesleki tükenmişlik düzeyini ölçmek üzere hazırlanmıştır. Ölçek Likert tipinde yedili derecelendirilmiş olup (Hiçbir zaman: 1 - Her zaman: 7) 10 maddeden oluşmaktadır. Ölçeğin uyarlama çalışmasına hemşire, öğretmen ve okul yöneticilerinden oluşan 460 evli birey katılmıştır. Tek boyutlu olan bu ölçek toplam puan hesaplanarak kullanılmaktadır. Ölçekten alınan puanların yükselmesi bireylerin mesleki tükenmişlik düzeylerinin de arttığı anlamına gelmektedir. Ölçeğin geçerliğine ilişkin yapılan açımlayıcı faktör analizi sonucunda açıklanan varyansın \%55.17'i olduğu ve faktör yük değerlerinin .52 ile .84 arasında değiştiği bulunmuştur. Ölçeğin güvenirliğine ilişkin yapılan analizler sonucunda ise Cronbach alfa iç tutarlık katsayısı 0.91 olarak hesaplanmıştır. Madde toplam test korelasyon değerlerinin 0.44 ile 0.77 arasında değiştiği, test tekrar test yöntemi sonucunda ortaya çıkan korelasyon değerinin ise 0.88 olduğu bulunmuştur. Yapılan bu analizler sonucunda ölçme aracının geçerli ve güvenilir bir biçimde kullanılabileceği değerlendirilmiştir. Ölçme aracının bu araştırma için geçerli ve güvenilir olup olmadığı kontrol edilmiştir. Ölçeğin geçerliği için doğrulayıcı faktör analizi yapılmıştır. Ulaşılan uyum iyiliği değerlerinin $\left(\chi^{2} / d f=4.12, \mathrm{GFI}=0.93, \mathrm{CFI}=, .90, \mathrm{RMSEA}=0.06, \mathrm{SRMR}=0.06\right)$ kabul edilebilir düzeyde olduğu görülmüştür (Tabachnick ve Fidell, 2015). Ölçeğin güvenirliği için hesaplanan Cronbach alfa iç tutarlılık katsayısının ölçeğin toplamı için: .90 olduğu belirlenmiştir.

\subsection{3. Örgütsel Yabancılaşma Ölçeği}

Eryılmaz (2010) tarafından geliştirilen bu ölçek bireylerin örgütsel yabancılaşma düzeyini belirlemek amacıyla hazırlanmıştır. 38 maddeden oluşan beşli Likert tipindeki ölçek 1= Hiçbir Zaman, 2= Nadiren, 3= Bazen, 4= Çoğu Zaman ve 5= Her Zaman şeklinde derecelendirilmiştir. Güçsüzlük, Anlamsızlık, Kuralıızık, Yalıtılmışlık ve Kendine Yabancılaşma olmak üzere beş boyutlu olan ölçek toplam puan hesaplanarak da kullanılabilmektedir. Ölçme aracından alınan puanların yükselmesi bireylerin yabancılaşmalarının da arttığı anlamına gelmektedir. Devlet okulunda ve özel okulda görev yapan 362 öğretmen üzerinde uygulanan ölçeğin geçerliğine ilişkin yapılan faktör analizi sonucuna göre beş boyutlu yapının açıkladığı varyansın \%55.86 olduğu ve maddelerin faktör yük değerlerinin .41 ile. 75 arasında değiştiği bulunmuştur. Ölçeğin güvenirliğine ilişkin yapılan analizler sonucunda ise alt boyutlara ilişkin elde edilen Cronbach alfa iç tutarlıık katsayısının .89 ile .67 arasında değiştiği saptanmıştır. Ayrıca ölçeğin toplam puanın test-tekrar test yöntemine dayalı olarak hesaplanan ilk ve ikinci uygulama arasındaki korelasyon değerinin .84 olduğu belirlenmiştir. Bu sonuçlar ışığında ölçme aracının geçerli ve güvenilir olduğu değerlendirilmiştir. Ölçme aracının bu araştırma için geçerli ve güvenilir olup olmadığı kontrol edilmiştir. Ölçeğin geçerliği için doğrulayıcı faktör analizi 
yapılmıştır. Ulaşılan uyum iyiliği değerlerinin $\left(\chi^{2} / d f=3.63, \mathrm{GFI}=0.94, \mathrm{CFI}=, .91, \mathrm{RMSEA}=0.05\right.$, SRMR=0.06) kabul edilebilir düzeyde olduğu görülmüştür (Tabachnick ve Fidell, 2015). Ölçeğin güvenirliği için hesaplanan Cronbach alfa iç tutarlılık katsayısının ölçeğin toplamı için: .92 olduğu belirlenmiştir.

\subsubsection{Kişisel Bilgi Formu}

Araştırma kapsamında geliştirilen bu form aracılığıyla katılımcıların cinsiyet, görev yapılan öğretim basamağı ve yaş bilgileri toplanmıştır.

\subsection{Verilerin Toplanması}

Araştırmada verilerin toplanması sürecinde öncelikle kullanılacak olan ölçme araçlarını geliştiren araştırmacılardan kullanım izinleri alınmıştır. Daha sonra ölçme araçlarının uygulanacağı şehirlerin milli eğitim müdürlüklerinden gerekli izinler alınmıştır. Bu aşamalardan sonra okullara gidilerek çalışma grubunu oluşturan psikolojik danışmanlara araştırmanın amaçları açıklanmıştır. Ayrıca elde edilecek verilerin gizli kalacağı konusunda kendilerine bilgi verilmiştir. Gönüllü olan katılımcılara ölçme araçları uygulanmıştır. Her bir uygulama yaklaşık $30 \mathrm{dk}$. sürmüştür.

\subsection{Verilerin Analizi}

Araştırmanın amacı olan psikolojik danışmanların yabancılaşmaları üzerinde öz yeterlik ve tükenmişliğin rolünün incelenmesi çoklu regresyon analizi ile gerçekleştirilmiştir. Bu analiz yapılmadan önce çoklu regresyon analizinin yapılabilmesi için gerekli görülen varsayımlar test edilmiştir. Varsayımların sağlandığı anlaşıldıktan sonra analizler yapılmıştır. Ayrıca araştırmanın değişkenlerinin bazı demografik özellikler açısından farklıık gösterip göstermediği de incelenmiştir. Bu doğrultuda değişkenlerin cinsiyet açısından karşılaştırılması $t$ testi ile görev yapılan öğretim basamağı ve yaş açısından karşılaştırılması ise ANOVA ile gerçekleştirilmiştir. Değinilen analizlerde SPSS 22 paket programı kullanılmıştır.

\section{BULGULAR}

$\mathrm{Bu}$ bölümde psikolojik danışmanların yabancılaşmaları üzerinde öz yeterlik ve tükenmişliğin rolünün incelenmesi amacıyla yapılan çoklu regresyon analizine ilişkin elde edilen bulgular sunulmuştur. Bu analiz yapılmadan önce gerekli görülen varsayımlar test edilmiştir. Ayrıca bu bölümde psikolojik danışmanların yabancılaşma, öz yeterlik ve tükenmişliklerinin cinsiyet, görev yapılan öğretim basamağı ve yaş açısından farklılık gösterip göstermediği belirlenmeye çalışılmıştır. Değinilen tüm bulgular sırasıyla aşağıda sunulmuştur.

\section{1. Çoklu Regresyon Analizinin Varsayımlarının Testine ilişkin Bulgular}

Araştırmanın amacı doğrultusunda çoklu regresyon analizinin yapılabilmesi için öncelikle gerekli görülen (Pallant, 2015) bazı varsayımların sağlanıp sağlanmadığı kontrol edilmiştir. Bu varsayımlar; 1. Uç Değerler, 2. Örneklem Büyüklüğü, 3. Doğrusallık, 4. Çoklu Ortak Doğrusallık (Multicollinearity) ve Teklilik (Singularity) ile 5. Normallik şeklindedir. Değinilen varsayımlar test edilmiş ve sağlandıkları anlaşıldıktan sonra çoklu regresyon analizi gerçekleştirilmiştir. Değinilen varsayımların kontrolüne ilişkin elde edilen bulgular aşağıda sunulmuştur.

\subsubsection{Uç Değerler}

Uç değerler tek değişkenli ve çok değişkenli olarak iki şekilde incelenmiştir. Tek değişkenli uç değerlerin tespit edilmesinde maddelere ilişkin hesaplanan z puanları dikkate alınmıştır. Çokluk'a vd. (2012) göre -3'den küçük ve +3 'den büyük z puanına sahip verilerin tek değişkenli uç değerler oldukları ifade edilmiştir. Yapılan hesaplamalara göre bu değerlere sahip 
verilerin olmadığı anlaşılmıştır. Araştırmada çok değişkenli uç değerlerin tespit edilmesinde ise Mahalanobis uzaklığı dikkate alınmıştır. Hesaplanan Mahalanobis değerinin, bağımsız değişken sayısını serbestlik derecesi alan $x^{2}$ tablo değeriyle karşılaştırılması gerekmektedir. Tablo değeri Mahalanobis değerinden büyük olan verilerin uç değer oldukları ve veri setinden çıkarılması gerektiği belirtilmiştir (Büyüköztürk, 2009).Analizde iki bağımsız değişken yer almaktadır. $x^{2}$ dağılım tablosunda iki bağımsız değişkene karşılık gelen 0.01 anlamlılık düzeyindeki serbestlik derecesi (sd) değeri 9.21'tir. Yapılan analiz sonucunda beş kişinin verisine ilişkin hesaplanan Mahalanobis değerinin değinilen tablo değerinden daha yüksek olduğu anlaşılmış ve bu veriler araştırmadan çıkarılmıştır. Yukarıda değinilen işlemler sonucunda tek değişkenli ve çok değişkenli uç değer probleminin olmadığı belirlenmiştir.

\subsection{2. Örneklem Büyüklüğü}

Araştırmada kullanılan ölçme araçları başlangıçta 220 kişiye uygulanmıştır. Ancak katılımcıların doldurdukları ölçme araçlarından 12 tanesinde çoğu maddenin eksik cevaplandırıldığı görüldüğünden bu ölçme araçları araştırmanın dışında tutulmuştur. Ayrıca daha önce değinildiği üzere çok değişkenli uç değerlere sahip olduğu belirlenen beş verinin de araştırmanın dışında tutulması sonucu katılımcı sayısı 203 kişi olmuştur. Tabachnick ve Fidell (2015) regresyon analizi için gerekli örneklem sayısının hesaplanmasında $\mathrm{N} \geq 50+8 \mathrm{~m}$ ( $m=$ bağımsız değişken sayısı) formülünü ortaya koymuştur. Araştırmanın bağımsız değişken sayısı 2 olduğu dikkate alınarak yapılan hesaplamaya göre (203>66)örneklem büyüklüğü koşulunun sağlandığı anlaşılmıştır.

\subsubsection{Doğrusallık}

Araştırmanın bağımsız değişkenleri (öz yeterlik ve tükenmişlik) ile bağımlı değişkeni (yabancılaşma)arasında doğrusal bir ilişkinin olup olmadığı kontrol edilmiştir. Elde edilen sonuçlar Şekil 1'de sunulmuştur.

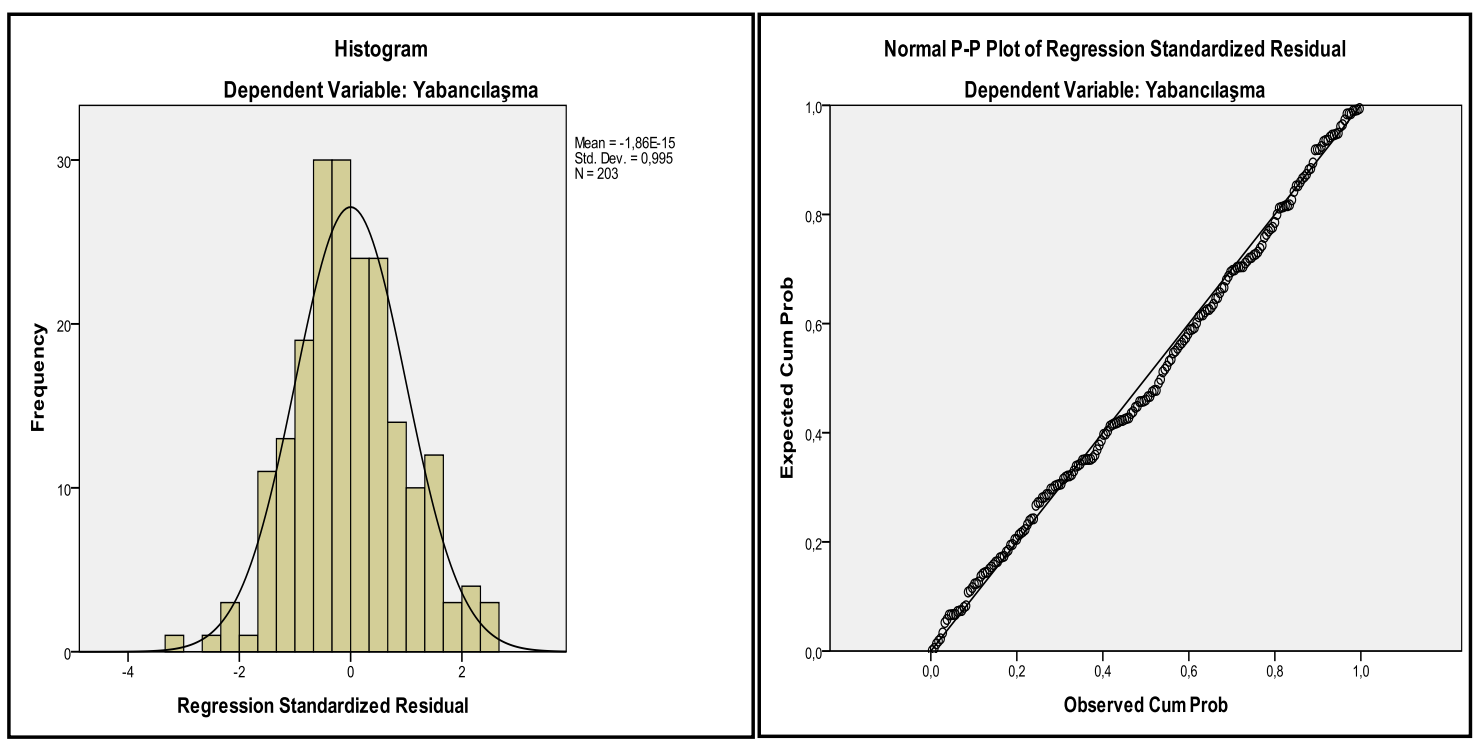

Şekil 1. Yabancılaşma ve öz yeterlik ile tükenmişliğe ilişkin histogram grafiği, saçılma diyagramı ve regresyon doğrusu

Şekil 1 incelendiğinde araştırmanın bağımsız değişkenleri (öz yeterlik ve tükenmişlik ile bağımlı değişkenine (yabancılaşma) ilişkin oluşturulan histogram ve saçılma diyagramlarında değişkenler arasında doğrusal bir ilişkinin olduğu görülebilmektedir. Dolayısıyla doğrusallık varsayımının sağlandığı söylenebilir.

\subsection{4. Çoklu Ortak Doğrusallık (Multicollinearity) ve Teklilik (Singularity)}


Araştırmanın bağımsız değişkenleri arasındaki ilişkilerin incelenmesi amacıyla yapılan korelasyon analizi sonuçlarına göre; öz yeterlik ile tükenmişlik ( $r=-.369)$ arasındaki ilişkinin.90'dan düşük olduğu anlaşıldığından çoklu ortak doğrusallık ve teklilik probleminin olmadığı değerlendirilmiştir (Pallant, 2015). Bu varsayımların test edilmesinde Varyans Büyütme Faktörü (VIF) ve Tolerans Değeri (TV) de hesaplanmıştır. Yapılan analizlerde elde edilen sonuçlar Tablo 2'de sunulmuştur. VIF değerinin $10^{\prime}$ dan küçük ve TV değerinin $.20^{\prime}$ den büyük olması durumunda çoklu bağlantı probleminin olmadığı kabul edilmektedir (Büyüköztürk, 2009). Elde edilen sonuçlara göre değişkenler arasında bu problemlerin olmadığı anlaşılmaktadır.

\subsubsection{Normallik}

Araştırmada değişkenlerinin normal dağılıma sahip olup olmadığının test edilmesi amacıyla çarpıklık (skewness) ve basıklık (kurtosis) değerleri hesaplanmıştır. Elde edilen sonuçlar Tablo 1'de sunulmuştur.

Tablo 1

Araştırmanın Değişkenlerine Iliş̧kin Çarpıklık (Skewness) ve Basıklık (Kurtosis) Değerleri

\begin{tabular}{ccc}
\hline Değişken & Çarpıklık (Skewness) & Basıklık (Kurtosis) \\
\hline Öz Yeterlik & -.044 & -.216 \\
Tükenmişlik & .514 & -.456 \\
Yabancılaşma & .757 & -.144 \\
\hline
\end{tabular}

Tablo 1 incelendiğinde değişkenlere ilişkin çarpıklık değerlerinin |3.0|'ten ve basıklık değerlerinin $|10.0|$ 'dan küçük olduğu görülmektedir. Bu değerlere göre araştırmanın değişkenlerinin normal dağılıma sahip oldukları kabul edilmiştir (Kline, 2015).

\section{2. Çoklu Regresyon Analizine İlişkin Elde Edilen Bulgular}

Bu araştırmanın temel amacı olan psikolojik danışmanların yabancılaşmaları üzerinde öz yeterlik ve tükenmişliğin rolünün belirlenmesi amacıyla çoklu regresyon analizi gerçekleştirilmiştir. Bu analizde psikolojik danışmanların öz yeterlik ve tükenmişliklerinin yabancılaşmalarını yordayıp yordamadığı incelenmiştir. Elde edilen sonuçlar Tablo 2'de sunulmuştur.

Tablo 2

Psikolojik Danışmanların Yabancılaşmalarının Yordanmasına Yönelik Yapılan Çoklu Regresyon Analizi

\begin{tabular}{cccccccccc}
\hline Değişken & $\mathbf{B}$ & Std. Hata & $\boldsymbol{\beta}$ & $\mathbf{t}$ & $\mathbf{P}$ & İkili $\boldsymbol{r}$ & Kısmi $\boldsymbol{r}$ & TV & VIF \\
\hline Sabit & 2.022 & .268 & & 7.534 & $.000^{* * *}$ & & & & \\
Öz Yeterlik & -.291 & .059 & -.254 & -4.892 & $.000^{* * *}$ & -.414 & -.327 & .927 & 1.078 \\
Tükenmişlik & .322 & .028 & .594 & 11.443 & $.000^{* * *}$ & .663 & .629 & .927 & 1.078 \\
\hline $\mathrm{R}=.71$ & $\mathrm{R}^{2}=.50$ & $\mathrm{~F}_{(2-200)}=$ & 99.759 & $\mathrm{p}=.000^{* * *}$ & & & & & \\
\hline
\end{tabular}

Tablo 2 incelendiğinde psikolojik danışmanların yabancılaşmaları ile öz yeterlikleri arasında olumsuz yönde orta düzeyde bir ilişkinin ( $r=-.41)$ olduğu ayrıca bu ilişkide tükenmişliğin etkisi kontrol edildiğinde benzer şekilde olumsuz yönde orta düzeyde bir ilişkinin ( $r=-.33)$ olduğu belirlenmiştir. Yabancılaşma ile tükenmişlik arasında ise olumlu yönde orta düzeyde bir ilişkinin ( $r=.66$ ) olduğu ayrıca bu ilişkide öz yeterliğin etkisi kontrol edildiğinde benzer şekilde iki değişken arasında olumlu yönde orta düzeyde bir ilişkinin ( $r=.63)$ olduğu belirlenmiştir. Psikolojik danışmanların öz yeterlik ve tükenmişliğinin birlikte yabancılaşmaları ile yüksek düzeyde olumlu yönde ilişkili olduğu ve değinilen değişkenlerin yabancılaşmanın \% 50 'sini açıkladığı ve oluşturulan modelin anlamlı olduğu görülmektedir $\left(R=.71, F_{(2-200)}=99.759\right.$, $p<.001)$. Standardize edilmiş regresyon katsayısına [ $\beta]$ göre yordayıcı değişkenlerin yabancılaşma üzerindeki önem sırasının; tükenmişlik ve öz yeterlik şeklinde olduğu 
anlaşılmaktadır. Ayrıca regresyon katsayılarının anlamlılığına ilişkin hesaplanan t-testi sonuçları incelendiğinde ise tükenmişliğin $(\beta=.594, p<.001)$ ve öz yeterliğin $(\beta=-.254, p<.001)$ yabancılaşmayı anlamlı şekilde açıkladığı görülmektedir.

\subsection{Demografik Değişkenlere İlişkin Elde Edilen Bulgular}

Bu araştırmada psikolojik danışmanların yabancılaşma, öz yeterlik ve tükenmişliklerinin demografik değişkenler açısından farklılaşıp farklılaşmadığı belirlenmeye çalışılmıştır. Bu amaçla cinsiyet açısından yapılan karşılaştırmalarda bağımsız örneklemler için $\mathrm{t}$ testi ve görev yapılan öğretim basamağı ile yaş açısından yapılan karşılaştırmalarda ise tek faktörlü varyans analizi (ANOVA) kullanılmıştır. Psikolojik danışmanların yabancılaşma, öz yeterlik ve tükenmişliklerinin cinsiyete göre anlamlı şekilde farklılık gösterip göstermediğini belirlemek amacıyla yapılan $t$ testi sonuçları Tablo 3'te sunulmuştur.

Tablo 3

Psikolojik Danışmanların Yabancılaşma, Öz Yeterlik ve Tükenmişliklerinin Cinsiyete Göre incelenmesi

\begin{tabular}{cccccccc}
\hline Değişken & Cinsiyet & $\mathbf{n}$ & $\overline{\mathbf{X}}$ & $\mathbf{S}$ & $\mathbf{S d}$ & $\mathbf{t}$ & $\mathbf{p}$ \\
\hline Yabancılaşma & Kadın & 134 & 1.81 & .57 & 201 & 1.517 & .131 \\
& Erkek & 69 & 1.69 & .45 & & & .268 \\
\hline Öz Yeterlik & Kadın & 134 & 3,93 & .50 & 201 & -1.110 & .016 \\
& Erkek & 69 & 4.01 & .39 & & & \\
\hline Tükenmişlik & Kadın & 134 & 2.90 & 1.05 & 201 & 2.425 & .016 \\
& Erkek & 69 & 2.55 & .82 & & & \\
\hline
\end{tabular}

Tablo 3 incelendiğinde psikolojik danışmanların yabancılaşma $\left(t_{201}=1.517, p>0.05\right)$ ve öz yeterliklerinin $\left(t_{201}=-1.110, p>0.05\right)$ cinsiyete göre anlamlı şekilde farklılaşmadığı anlaşılmıştır. Bununla birlikte psikolojik danışmanların tükenmişliklerinin cinsiyete göre anlamlı farklılık gösterdiği $\left(\mathrm{t}_{201}=2.425, \mathrm{p}<0.05\right)$ ve kadınların $(\overline{\mathrm{x}}=2.90)$, erkeklerden $(\overline{\mathrm{x}}=2.55)$ daha fazla tükenmişlik yaşadıkları belirlenmiştir. Bu sonuçlara göre cinsiyetin psikolojik danışmanların yabancılaşma ve öz yeterliklerini etkilemeyen bunun yanı sıra tükenmişliklerini etkileyen bir faktör olduğu söylenebilir. Psikolojik danışmanların yabancılaşma, öz yeterlik ve tükenmişliklerinin görev yapılan öğretim basamağına göre anlamlı şekilde farklılık gösterip göstermediğini belirlemek amacıyla yapılan ANOVA testi sonuçları Tablo 4'te sunulmuştur.

Tablo 4

Psikolojik Danışmanların Yabancılaşma, Öz Yeterlik ve Tükenmişliklerinin Görev Yapılan Öğretim Basamağına Göre incelenmesi

\begin{tabular}{cccccccc}
\hline Değişken & Görev Yapılan Öğretim Basamağı & $\mathbf{n}$ & $\overline{\mathbf{X}}$ & $\mathbf{S}$ & $\mathbf{s d}$ & $\mathbf{F}$ & $\mathbf{P}$ \\
\hline Yabancılaşma & Illkokul & 65 & 1.78 & .61 & 2 & .157 & .855 \\
& Ortaokul & 73 & 1.77 & .49 & 200 & & \\
& Lise & 65 & 1.73 & .51 & 202 & & \\
\hline Öz Yeterlik & ilkokul & 65 & 4.01 & .45 & 2 & 1.511 & .223 \\
& Ortaokul & 73 & 3.88 & .50 & 200 & & \\
& Lise & 65 & 3.98 & .45 & 202 & & \\
\hline Tükenmişlik & ilkokul & 65 & 2.61 & .88 & 2 & 1.806 & .167 \\
& Ortaokul & 73 & 2.93 & .96 & 200 & & \\
& Lise & 65 & 2.78 & 1.10 & 202 & & \\
\hline
\end{tabular}

Tablo 4 incelendiğinde psikolojik danışmanların yabancılaşma $\left(F_{2-200}=.157, p>0.05\right)$, öz yeterlik $\left(F_{2-200}=1.511, p>0.05\right)$ ve tükenmişliklerinin $\left(F_{2-200}=1.806, p>0.05\right)$ görev yapılan öğretim basamağına göre anlamlı şekilde farklılaşmadığı anlaşılmıştır. Bu sonuçlara göre görev yapılan öğretim basamağının psikolojik danışmanların yabancılaşma, öz yeterlik ve tükenmişliklerini etkileyen bir faktör olmadığı söylenebilir. Psikolojik danışmanların yabancılaşma, öz yeterlik ve 
tükenmişliklerinin yaşa göre anlamlı şekilde farklılık gösterip göstermediğini belirlemek amacıyla yapılan ANOVA testi sonuçları Tablo 5'te sunulmuştur.

Tablo 5

Psikolojik Danışmanların Yabancılaşma, Öz Yeterlik ve Tükenmişliklerinin Yaşa Göre incelenmesi

\begin{tabular}{|c|c|c|c|c|c|c|c|}
\hline Değişken & Yaş & $\mathbf{n}$ & $\bar{x}$ & $S$ & Sd & $\mathbf{F}$ & $\mathbf{P}$ \\
\hline \multirow[t]{4}{*}{ Yabancılaşma } & $22-24$ & 51 & 1.70 & .45 & 3 & .680 & .565 \\
\hline & $25-27$ & 64 & 1.83 & .58 & 199 & & \\
\hline & $28-32$ & 44 & 1.80 & .54 & 202 & & \\
\hline & $33-54$ & 44 & 1.72 & .55 & & & \\
\hline \multirow[t]{4}{*}{ Öz Yeterlik } & $22-24$ & 51 & 3.87 & .46 & 3 & .858 & .464 \\
\hline & $25-27$ & 64 & 3.97 & .46 & 199 & & \\
\hline & $28-32$ & 44 & 3.98 & .42 & 202 & & \\
\hline & $33-54$ & 44 & 4.01 & .53 & & & \\
\hline \multirow[t]{4}{*}{ Tükenmişlik } & $22-24$ & 51 & 2.85 & 1.09 & 3 & 1.323 & .268 \\
\hline & $25-27$ & 64 & 2.92 & 1.01 & 199 & & \\
\hline & $28-32$ & 44 & 2.71 & .86 & 202 & & \\
\hline & $33-54$ & 44 & 2.56 & .95 & & & \\
\hline
\end{tabular}

Tablo 5 incelendiğinde psikolojik danışmanların yabancılaşma $\left(F_{3-199}=.680, p>0.05\right)$, öz yeterlik $\left(F_{3-199}=.858, p>0.05\right)$ ve tükenmişliklerinin $\left(F_{3-199}=1.323, p>0.05\right)$ yaşa göre anlamlı şekilde farklılaşmadığı anlaşılmıştır. Bu sonuçlara göre yaşın psikolojik danışmanların yabancılaşma, öz yeterlik ve tükenmişliklerini etkileyen bir faktör olmadığı söylenebilir.

\section{TARTIŞMA, SONUÇ VE ÖNERILER}

Araştırmanın sonucunda psikolojik danışmanların öz yeterlikleri ile yabancılaşmaları arasında orta düzeyde ve olumsuz yönde bir ilişki bulunmuştur. Bu konuyla ilgili olarak ve bu çalışmanın sonucunu destekleyen Larson ve Daniels'in (1998) 32 araştırmayı incelediği çalışmada, psikolojik danışmanların çevreden gördükleri destek ile öz yeterlikleri arasında olumlu yönde anlamlı bir ilişki olduğu bulunmuştur. Dolayısıyla psikolojik danışmanların görev yaptıkları kuruma yabancılaşmamalarının yani kurumları içerisinde destek görmelerinin öz yeterlikleri ile olumlu yönde ilişkisinin olduğu anlaşılmaktadır. Diğer bir araştırmada ise Çağlar (2013) 875 öğretmen adayı ile yaptığı çalışmada yabancılaşma ile öğretmenlik mesleğine yönelik tutum arasında olumsuz yönde bir ilişkinin olduğunu bulmuştur. Bu sonuca göre bireylerin öz yeterlikleri ile ilişkili olabileceği düşünülen mesleklerine yönelik olumlu tutum ile yabancılaşma arasında ters yönlü bir ilişkinin olduğu anlaşılmaktadır. Bu konuda Özgözgü’nün vd. (2017) yaptıkları araştırmada ise psikolojik danışmanların öz yeterlikleri ile çalıştıkları kurumla bağı ile ilgili olan örgütsel özdeşleşme arasında olumlu yönde anlamlı bir ilişkinin olduğu sonucuna ulaşılmıştır. Bu araştırma sonuçları beraber ele alındığında psikolojik danışmanların öz yeterliklerinin görev yaptıkları kurum içerisindeki olumlu ya da olumsuz yaşantılardan etkilendiği anlaşılmaktadır. Ayrıca Al-Darmaki'nin (2005) 113 psikolojik danışman ile yaptığı araştırmada öz yeterlik ile kaygı arasında olumsuz yönde, problem çözme becerisi arasında ise olumlu yönde anlamlı bir ilişkinin olduğu bulunmuştur. Cheng'ın vd. (2011) 108 psikolojik danışman ile yaptıkları araştırmada ise öz yeterlik ve olumlu başa çıkma arasında olumlu yönde anlamlı bir ilişkinin olduğu ortaya koyulmuştur. Bu sonuçlar ise psikolojik danışmanların öz yeterliklerinin örgütsel süreçler ile ilişkili olduğu gibi bireysel özellikler ile de ilişkili olduğunu göstermektedir. Araştırmadan elde edilen sonuç ve bu sonuçlar birlikte değerlendirildiğinde psikolojik danışmanların öz yeterliklerinin görev yaptıkları kurum içerisindeki olumlu ya da olumsuz yaşantılar ile çeşitli kişisel özelliklerden etkilendiği ve öz yeterliklerinin yükselmesi ile çalıştıkları kuruma yabancılaşmalarının azaldığı anlaşıımaktadır. Farklı bir ifadeyle kendilerini mesleklerinde yeterli görenlerin kurumlarına daha az yabancılaştıkları ifade edilebilir. 
Araştırmada psikolojik danışmanların tükenmişlikleri ile yabancılaşmaları arasında orta düzeyde olumlu yönde bir ilişki bulunmuştur. Özçınar'ın (2011) yapmış olduğu çalışmada yabancılaşma ve tükenmişlik arasında olumlu yönde anlamlı bir ilişkinin olduğu tespit edilmiştir. Dolayısıyla araştırmadan elde edilen sonuç ile bu sonucun paralel olduğu anlaşılmaktadır. Tükenmişliğin nedenlerinin incelendiği araştırmalardan Bardhoshi'nin vd. (2014) 252 psikolojik danışmanla yaptığı çalışmada psikolojik danışmanların, psikolojik danışmanlık dışında işlerle görevlendirilmesinin tükenmişlik yaşamalarına neden olduğu ortaya çıkmıştır. Bu konuyla ilgili olarak Güven'in (2009) okul müfettişleri ile yaptığı araştırmanın sonucunda okul yöneticileri ile psikolojik danışmanlar arasında yeterli iletişimin olmadığı, okullarda görev yapan psikolojik danışman sayısının yetersiz olduğu ve sınıf rehberlik programının etkili şekilde uygulanmadığı görüşlerinin paylaşıldığı bulunmuştur. Aydın vd. (2011) tarafından 260 rehber öğretmen ve 175 okul yöneticisi ile yaptığı araştırmanın sonucunda okul yöneticilerinin psikolojik danışmanların görev kapsamını yeterince bilmedikleri ve kendilerine görev alanlarının dışında çalışmalar yaptırmak istedikleri ortaya koyulmuştur. Bu durumun ise çatışmaları beraberinde getirdiği belirtilmiştir. Kızıl'ın (2007) psikolojik danışmanlar ve sınıf rehber öğretmenleri ile yaptığı araştırmanın sonucunda rehberlik etkinliklerine ayrılan sürenin yeterli olmadığı, öğretmenler ile psikolojik danışmanlar arasındaki iletişimin yetersiz olduğu, öğretmenlerin rehberlik ile ilgili yeterince bilgi sahibi olmadığı ortaya koyulmuştur. Camadan'ın vd. (2016) 20 psikolojik danışman ile yaptıkları araştırmanın sonucunda ise yaşadıkları yabancılaşmanın nedeni olarak "evrak ve idari işlerin yaptırılmak istenmesi gibi görev dışı istek ve beklentiler", "rehberlik hizmetlerinin öğretmenler tarafından önemsiz görülmesi gibi rehberlik hizmetleriyle ilgili olumsuz görüşler" ve "rehber öğretmenlerden görevleri dışında işler beklenmesi gibi rehberlik ve psikolojik danışmanlık mesleğinin yeterince anlaşılmaması" durumlarını ifade etmişlerdir. Bu sonuçlara göre rehberlik hizmetlerine yönelik algı, görüş, beklenti ve uygulamadaki bir takım aksaklıkların psikolojik danışmanların yabancılaşmaları üzerinde etkisi olduğu anlaşılmaktadır. Yapması gereken işten uzaklaşan ve çalışma ortamında yeterli desteği göremeyen bireyin yabancılaşma yaşamasının da muhtemel olacağı anlaşımaktadır. Dolayısıyla çalıştıkları kurumda karşılaştıkları istenmeyen durumların psikolojik danışmanların motivasyonlarını olumsuz yönde etkilediği söylenebilir. Bu bağlamda araştırmadan elde edilen sonuca göre bireylerin mesleki olarak tükendikleri ölçüde çalıştıkları kurumda kendilerini yabancılaşmış hissettikleri düşünülmektedir.

Diğer bir sonuç olarak araştırmada psikolojik danışmanların öz yeterlikleri ile tükenmişlikleri arasında orta düzeyde ve olumsuz yönde bir ilişki bulunmuştur. Bu sonucu destekler nitelikte Wachter'in vd. (2008) 249 psikolojik danışmanla yaptıkları araştırmada psikolojik danışmanların öz saygıları ve kendilerini olumlu yönde algılayış biçimleri ile tükenmişlikleri arasında ters yönlü bir ilişkinin olduğu saptanmıştır. Bu sonuca benzer şekilde Butler'in (2005) 533 psikolojik danışmanla yaptığı araştırmada psikolojik danışmanların benlik saygıları ile tükenmişlikleri arasında olumsuz yönde bir ilişkinin olduğu ortaya koyulmuştur. Öz saygısı, kendini algılayış biçimi ve benlik saygısı gibi değişkenlerinin öz yeterlik ile benzerlik gösterebileceği düşüncesinden hareketle değinilen araştırma sonuçlarının, bu araştırmadan elde edilen sonuç ile tutarlılık gösterdiği söylenebilir. Bu konuya ışık tutacağı düşünülen Erkan Atik'in (2011) yaptığı araştırmada okul psikolojik danışmanı öz yeterliği ile eğitim yaşantılarına yönelik memnuniyetin olumlu yönde ilişkili olduğu saptanmıştır. Bu sonuca dayalı olarak öz yeterliği yüksek olan psikolojik danışmanların eğitim yaşantılarına yönelik olumlu bir algı geliştirdikleri ve mesleklerini icra ederken karşılaştıkları problem durumlarında kendilerini yenileme yolunu tercih ederek tükenmişliğin önüne geçtikleri söylenebilir. Belgi (2016) tarafından devlet ve özel liselerde görev yapan psikolojik danışmanlarla yapılan çalışmada ise psikolojik danışmanların kendileri ve meslekleri konusunda yaşadıkları güven duygusunun tükenmişliği azalttığı sonucuna ulaşılmıştır. Ayrıca mesleki tecrübesi fazla olan, bilgi birikimi ve 
uygulamalar konusunda etkin olan psikolojik danışmanların tükenmişliklerinin, meslekte yeni olanlara göre daha düşük düzeyde olduğu ortaya koyulmuştur. Değinilen özelliklerin öz yeterlik ile ilişkili olduğu değerlendirildiğinde elde edilen sonuçlar ile bu araştırmanın sonuçlarının paralellik gösterdiği söylenebilir. Yukarıda değinilen araştırmaların sonuçları ve bu araştırmanın sonucundan hareketle psikolojik danışmanların kendilerini mesleklerinde yeterli görmeleriyle tükenmişlik yaşamalarının ters orantılı olduğu değerlendirilebilir. Farklı bir ifadeyle kendilerini mesleklerinde yetersiz hisseden psikolojik danışmanların daha fazla bitkinlik, yılgınlık ve enerji kaybı gibi durumlar ile karşılaştıkları anlaşılmaktadır.

Psikolojik danışmanların yabancılaşmaları üzerinde öz yeterlik ve tükenmişliğin rolünün incelendiği bu araştırmada, psikolojik danışmalarda yabancılaşma yaşanmasının öz yeterlik ve tükenmişlik değişkenleri tarafından açıklandığı bulunmuştur. Psikolojik danışmanların öz yeterlikleri yükseldikçe yabancılaşmalarının azaldığı; tükenmişlikleri yükseldikçe de yabancılaşmalarının arttı̆̆ı sonuçlarına varılmıştır. Ayrıca öz yeterlikleri yükseldikçe tükenmişliklerinin de azaldığı ortaya çıkmıştır. Bununla birlikte psikolojik danışmanların tükenmişliklerinin, öz yeterliklerine göre yabancılaşmanın daha anlamlı bir yordayıcısı olduğu sonucuna ulaşılmıştır. Bu sonuçlardan hareketle psikolojik danışmanların öz yeterliklerinin yüksek olmasının çalıştıkları kurumdan ve yaptıkları işten uzaklaşmalarını engellediği söylenebilir. Farklı bir ifadeyle kendilerini mesleklerinde yeterli gören psikolojik danışmanların çalıştıkları kurumun kültürüne daha kolay uyum sağladığı ve bunun sonucunda daha az yabancılaşma yaşadıkları ifade edilebilir. Araştırma sonucunda psikolojik danışmanların yaşadıkları tükenmişliğin artmasının yabancılaşmalarını artıran bir durum olduğu belirlenmiştir. Bu sonuçtan hareketle psikolojik danışmanların kendilerini mesleki yaşantılarında yorgun, bitkin ve yetersiz hissetmelerinin çalıştıkları kuruma kendilerini daha fazla yabancı hissetmelerine neden olabildiği söylenebilir. Ayrıca psikolojik danışmanların mesleklerinde başarılı ve yetkin olacaklarına olan inançları yükseldikçe mesleklerinde kendilerini daha az yorgun ve bıkmış hissedecekleri anlaşılmaktadır. Araştırmadan elde edilen bu sonuçlar beraber değerlendirildiğinde psikolojik danışmanların kendilerini mesleklerinde yetkin olarak algılamamalarının kendilerini daha fazla yıpranmış hissetmelerine yol açacağı ve bu durumun ise çalıştıkları kuruma daha fazla yabancılaşmalarına etki edeceği değerlendirilmektedir.

Yabancılaşmanın demografik değişkenler açısından incelenmesine dayalı olarak cinsiyet değişkenine göre psikolojik danışmanların yabancılaşmaları arasında herhangi anlamlı bir farklılık bulunmamıştır. Bu konuda Fayda Kınık'ın (2010) ilk ve orta dereceli okullardaki 300 öğretmenle ve Temel, Mirzeoğlu ve Mirzeoğlu'nun (2013) ilköğretimde görev yapan 408 beden eğitimi öğretmeniyle yaptıkları araştırmada kadın öğretmenlerin erkeklere göre daha fazla yabancılaşma yaşadıkları sonucuna ulaşıımıştır. Kesik ve Cömert'in (2014) ilköğretimde görev yapan 719 öğretmenle yaptığı araştırmada ise erkek öğretmenlerin kadınlara göre daha fazla yabancılaşma yaşadıkları belirtilmiştir. Benzer şekilde Ataş ve Ayık'ın (2013) ve Çağlar'ın (2013) öğretmen adayları ile yaptığı çalışmada erkeklerin kadınlara göre okula daha fazla yabancılaştığı ortaya koyulmuştur. Boz'un (2014) lisede görev yapan 146 öğretmen ile yaptığı araştırmada ise yalıtılmışlık boyutunda kadın öğretmenlerin, okula yabancılaşma boyutunda ise erkek öğretmenlerin yabancılaşmalarının daha yüksek olduğu sonucuna ulaşılmıştır. Yukarıda yer alan araştırma sonuçlarının bu araştırma sonucu ile çeliştiği anlaşılmaktadır. Elma'nın (2003), ilköğretimde görev yapan, Eryılmaz'ın (2010) orta öğretimde görev yapan ve Kasapoğlu'nun (2015) ilkokulda görev yapan öğretmenler ile yaptıkları araştırmalarda ise yabancılaşmanın cinsiyete göre farklılaşmadığı ortaya koyulmuştur. Bu sonuçlar ise araştırmadan elde edilen sonuçla örtüşmektedir. Araştırmadan elde edilen bu sonuca göre psikolojik danışmanların cinsiyetlerinin yabancılaşmalarını açıklayan bir değişken olmadığı anlaşılmaktadır. Kişinin yaşadığı yabancılaşma üzerinde cinsiyet değişkeni dışında olan çalışanlarla ilişkisinde kullandığı iletişim becerileri, karar verme süreçlerine katılım durumu ve 
yönetimin kendisinden beklentileri gibi faktörlerin etkili olabileceği değerlendirilmiştir. Araştırmada psikolojik danışmanların yabancılaşmalarının görev yapılan öğretim basamağına göre farklılaşmadığı bulunmuştur. Bu konuda yapılan araştırmalar incelendiğinde bu araştırma sonucuyla çelişen sonuçlara rastlanmaktadır. Fayda Kınık'ın (2010), ilk ve orta dereceli okullardaki 300 öğretmenle yaptığı araştırmada, ilköğretimde çalışan öğretmenlerin ortaöğretimde çalışan öğretmenlere göre yabancılaşmalarının daha yüksek olduğu bulunmuştur. Temel'in vd. (2013), 408 beden eğitimi öğretmeniyle yaptığı araştırmada ilkokulda çalışan öğretmenlerin ortaokulda çalışanlara göre yabancılaşmalarının daha yüksek olduğu saptanmıştır. Bahsedilen sonuçların yanı sıra bu araştırma sonucuna dayalı olarak psikolojik danışmanların yabancılaşmalarının görev yapılan öğretim basamağı açısından farklılaşmadığı belirlenmiştir. Değinilen öğretim basamaklarında benzer yönetim anlayışı, kurum kültürü ve örgüt iklimi gibi durumların var olabileceği düşünülmüştür. Bunun etkisiyle öğretim basamağının farklılaşmasının psikolojik danışmanların yabancılaşmaları üzerinde herhangi bir değişikliğe neden olmadığı değerlendirilmektedir. Diğer bir sonuca göre psikolojik danışmanların yabancılaşmalarının yaşlarına göre farklılık göstermediği bulunmuştur. Fayda Kınık'ın (2010), ilk ve orta dereceli okullardaki 300 öğretmenle yapmış olduğu araştırmada ise yabancılaşmada yaşa göre bir farklılı̆ın olmadığı belirtildiğinden bu araştırmanın sonucunu desteklediği söylenebilir. Bu konuda yapılan diğer araştırmalar incelendiğinde; Kasapoğlu'nun (2015) ilkokulda görev yapan 403 öğretmen ile yaptığı çalışmada 36-45 yaşındaki öğretmenlerin yaşı ileri olan öğretmenlere göre daha fazla yabancılaşma yaşadıkları sonucuna ulaşılmıştır. Boz' un (2014), lisede görev yapan 146 öğretmenle yapmış olduğu çalışmada 50 yaş ve üzerindeki öğretmenlerin 30-40 yaş arasındaki öğretmenlere göre yabancılaşmanın yalıtılmışık boyutunda daha yüksek puanlar aldıkları görülmüştür. Yukarıda bahsi geçen araştırma sonuçlarının bu araştırma sonucu ile çeliştiği görülmektedir. Bu araştırmadan elde edilen sonuç değerlendirildiğinde psikolojik danışmanların yabancılaşmalarının yaşları ile ilgili olmadığı anlaşılmaktadır. Yabancılaşmanın çalışma koşulları, çalışanlara sunulan fırsatlar ya da yaşatılan zorluklarla ilgili bir durum olabileceğinden kişinin yabancılaşmasında yaşın önemli bir değişken olmadığı söylenebilir.

Öz yeterliğin demografik değişkenler açısından incelenmesine dayalı olarak cinsiyet değişkenine göre psikolojik danışmanların öz yeterlikleri arasında herhangi anlamlı bir farklıık bulunmamıştır. Bu sonuçla örtüşür şekilde bu konuda yapılan araştırmalarda psikolojik danışmanların öz yeterliklerinin cinsiyetleri açısından anlamlı farklılık göstermediği sonucuna ulaşılmıştır (Aksoy ve Diken, 2009; Bilgiç, 2011; Erkan Atik, 2011). Bu sonuçlardan farklı olarak Gündüz ve Çelikali'nin (2007) 194 psikolojik danışman üzerinde yapmış olduğu araştırmanın sonucunda; kadınların öz yeterliklerinin erkeklere göre daha yüksek olduğu saptanmıştır. Bu araştırmanın sonucu ise psikolojik danışmanların öz yeterlikleri üzerinde cinsiyet değişkeninin anlamlı bir farklılaşmaya neden olmadığı yönündedir. Rehberlik hizmetlerini yürüten kişinin cinsiyetinin süreç üzerinde etkili olması istenmeyen bir durumdur. Bu yönüyle psikolojik danışmanların cinsiyetlerinin öz yeterliklerini etkilememesi de verilen hizmetler açısından olumlu bir durumdur. Araştırmada psikolojik danışmanların öz yeterliklerinin görev yapılan öğretim basamağına göre farklılık göstermediği saptanmıştır. Bu sonuçla benzer şekilde Asarlı'nın (2012) çalışmasında görev yapılan öğretim basamağı ile psikolojik danışmanların öz yeterlikleri arasında bir ilişkinin olmadığı sonucuna ulaşılmıştır. Gündüz ve Çelikali (2007) de yaptıkları araştırmada öz yeterlik ile ilköğretim ya da ortaöğretim kurumlarında çalışma durumunun ilişkili olmadığı sonucuna ulaşmışlardır. Bu araştırma sonuçları ve araştırmadan elde edilen sonuç birlikte değerlendirildiğinde psikolojik danışmanların görev yaptıkları öğretim basamağının öz yeterlik açısından her hangi bir farklılı̆̆a yol açmadığı anlaşılmaktadır. Öz yeterlik bireyin bir işi yapabilmesine yönelik kişisel algısı ile ilgili olduğu için görev yaptığı öğretim basamağının koşul ve olanakların farklılaşmasının bu algı üzerinde tek başına etkili 
olmadığı anlaşılmıştır. Araştırmanın diğer bir sonucu psikolojik danışmanların öz yeterliklerinin yaşlarına göre farklılaşmadığıdır. Bu sonuçla benzer şekilde Erkan Atik'in (2011) yaptığı araştırmanın sonucunda psikolojik danışmanların öz yeterlikleri ile yaşları arasında herhangi bir ilişkinin olmadığı bulunmuştur. Aksoy ve Diken'in (2009) yapmış olduğu çalışma da bu araştırmanın sonucunu destekler niteliktedir. Dolayısıyla gerek bu araştırmadan elde edilen sonuç gerekse değinilen araştırma sonuçları psikolojik danışmanların yaşlarının öz yeterliklerini açıklayan bir değişken olmadığını göstermektedir. Yaş faktörünün bireyler üzerindeki etkisi farklı olabilmektedir. Örneğin göreve yeni başlayan bir psikolojik danışman idealist düşünceleri sayesinde yüksek bir öz yeterliğe sahip olabilirken; göreve yeni başlayan başka bir psikolojik danışman tecrübesizliği nedeniyle düşük bir öz yeterlik içerisinde olabilir. Benzer şekilde yaşı ileri olan bir psikolojik danışman mesleki tecrübesinin etkisiyle yüksek öz yeterlik sahibi olabileceği gibi eğitimini almadığı güncel konular veya problemler karşısında yaşayacağı zorluklar sonucunda kendisini yetersiz hissedebilir. Dolayısıyla farklı yaş grubundaki bireylerin öz yeterliklerini etkileyen çeşitli değişkenler olabilir. Bu yönüyle yaşın öz yeterlik üzerinde tek başına etkili bir değişken olmadığı söylenebilir.

Tükenmişliğin demografik değişkenler açısından incelenmesine dayalı olarak kadın psikolojik danışmanların erkek psikolojik danışmanlardan daha fazla tükenmişlik yaşadığı sonucuna ulaşılmıştır. Tükenmişlik ile cinsiyet arasındaki ilişkiyi inceleyen araştırmalara bakıldığında; Akten'in (2007) kamu ve özel sektörde görev yapan 304, Yıldız'ın (2012) resmi ve özel ortaöğretim kurumlarında görev yapan 196, Aydemir'in (2014) ilkokul ve ortaokulda görev yapan 178 ve Umay'ın (2015) resmi ve özel ilkokul, ortaokul ve lise kademelerinde görev yapan 230 psikolojik danışmanla yaptığı araştırmalarda kadın öğretmenlerin duygusal tükenme boyutunda erkek öğretmenlerden daha yüksek düzeyde tükenmişlik yaşadıkları sonucuna ulaşılmıştır. Belgi (2016) tarafından devlet ve özel liselerde görev yapan 60 psikolojik danışmanla yapılan araştırmaya göre ise erkek psikolojik danışmanların duyarsızlaşma düzeylerinin kadınlardan daha yüksek olduğu saptanmıştır. Bu araştırmaların aksine Başören'in (2005) 115, Kaya'nın (2009) 260, İkiz'in (2010) 120 ve Çınar'ın (2016) 420 psikolojik danışmanla yapmış oldukları araştırmalarda erkek ve kadın psikolojik danışmanların tükenmişlikleri arasında herhangi anlamlı bir farklılık olmadığı belirlenmiştir. Yukarıda değinilen araştırmalar ve bu araştırmanın sonucu birlikte değerlendirildiğinde tükenmişliğin cinsiyete göre farklılaştığı anlaşılmaktadır. Kadın psikolojik danışmanların erkeklere göre daha fazla tükenmişlik yaşamalarının nedeni ise toplumsal cinsiyet rolleri kapsamında irdelenebilir. Türkiye'de kadın ve erkeklerden beklenen rollerin adil olmadığı düşünülmektedir. Erkeğin iş yerindeki çalışmalarını yapması onun için çoğunlukla yeterli görülürken aynı durum kadın için geçerli olmamaktadır. Çocukların bakımı, yemek ve temizlik gibi ev işleri de genellikle kadından beklenen rollerdir. Çalışma hayatındaki yorgunluk evdeki işlerin sorumluluğu ile birleşince kadınlarda tükenmişliğin daha fazla yaşanması sonucunun ortaya çıktığı söylenebilir. Araştırmada psikolojik danışmanların tükenmişliklerinin görev yapılan öğretim basamağına göre farklılık göstermediği saptanmıştır. Bu sonuçtan farklı olarak i̇kiz (2010) ilköğretimde çalışan 120 psikolojik danışmanla ve Akten (2007) 304 psikolojik danışmanla yaptığı çalışmada duyarsızlaşma boyutunda lisede çalışan psikolojik danışmanların daha yüksek düzeyde tükenmişlik yaşadığı sonuçlarına ulaşmışlardır. Bununla birlikte araştırmadan elde edilen sonuçla örtüşür şekilde Başören'in (2005) 96 psikolojik danışmanla ve Çınar'ın (2016) 420 psikolojik danışmanla yaptıkları çalışmalarda tükenmişliğin görev yapılan öğretim basamağına göre farklılaşmadığı saptanmıştır. Dolayısıyla bu sonuçlar ve araştırmadan elde edilen sonuca dayalı olarak görev yapılan öğretim basamağının psikolojik danışmanların tükenmişliğini açıklayan bir değişken olmadığı sonucuna varılabilir. Bilindiği üzere rehberlik hizmetleri problem alanına göre eğitsel, mesleki ve kişisel-sosyal rehberlik olmak üzere üçe ayrılmaktadır. Değinilen rehberlik hizmetlerinin içeriği öğretim basamaklarına göre farklılık gösterse de amaç 
olarak benzerlik içermektedir. Farklı bir ifadeyle her öğretim basamağında öğrenim gören öğrencinin kazanması gereken becerileri ve çözülmesi gereken problemleri bulunmaktadır. Dolayısıyla psikolojik danışmanlar her ne kadar farklı öğretim basamağında görev yapıyor olsalar dahi kendilerinden beklenen görev ve sorumluluklar benzerlik göstermektedir. Dolayısıyla psikolojik danışmanların yaptıkları hizmetler öğretim basamağı açısından benzerlik gösterdiğinden, öğretim basamağının tükenmişlikleri üzerinde herhangi bir farklılı̆a neden olmadığı söylenebilir. Araştırmanın diğer bir sonucunda psikolojik danışmanların tükenmişliklerinin yaşa göre farklılık göstermediği bulunmuştur. Tükenmişlik ile yaş arasındaki ilişkiyi inceleyen araştırmalarda bu sonuçtan farklı olarak Kaya (2009) 260 psikolojik danışmanla yaptığı çalışmasında 31-40 yaş arasındaki psikolojik danışmanların diğer yaştakilere göre daha düşük düzeyde tükenmişlik yaşadığı sonucuna ulaşmıştır. İkiz (2010) 120 psikolojik danışmanla, Yıldız (2012) resmi ve özel ortaöğretim kurumlarında görev yapan 196 psikolojik danışmanla, Aydemir (2014) ilkokul ve ortaokulda görev yapan 178 psikolojik danışmanla ve Çınar (2016) 420 psikolojik danışmanla yaptıkları çalışmalarda; bu araştırmada olduğu gibi psikolojik danışmanların tükenmişliklerinin yaşlarına göre farklılaşmadığı sonucuna ulaşmışlardır. Bu sonuçlara dayalı olarak yaşın psikolojik danışmanların tükenmişlikleri üzerinde etken bir rolünün olmadığı anlaşılmaktadır. Göreve yeni başlayan psikolojik danışmanların mesleğe yeni başlama heyecanı ile kendilerini dinamik hissetmelerinin; mesleklerinde tecrübeli psikolojik danışmanların ise deneyimleri sayesinde kendilerini işinde başarılı hissetmelerinin tükenmişlik yaşamalarını engellediği söylenebilir.

Araştırmanın demografik değişkenlerine ilişkin elde edilen sonuçlar değerlendirildiğinde psikolojik danışmanların yabancılaşma ve öz yeterliklerinin cinsiyetlerine göre farklılık göstermediği bulunmuştur. Tükenmişliğin ise kadınlarda daha yaygın yaşandığı anlaşılmıştır. Ayrıca bu araştırmada psikolojik danışmanların öz yeterlik, tükenmişlik ve yabancılaşmalarının yaşları ve görev yapılan öğretim basamağına göre farklılık göstermediği saptanmıştır. Sonuç olarak psikolojik danışmanların kendisinden, çalıştıkları okuldan, yaşadığı toplumsal, psikolojik ve kültürel ortamdan uzaklaşmaları; duyarsızlaşmaları, enerjisini yitirmeleri ve mesleki yetkinlik algılarının görev yapılan öğretim basamağı ve yaş değişkenleri ile açıklanamadığı savunulabilir. Bununla birlikte psikolojik danışmanların kadın veya erkek olmasının mesleklerinde yıpranmalarında ve enerjilerini kaybetmelerinde etkili olduğu söylenebilir.

Ileride yapılacak araştırmalarda psikolojik danışmanların yabancılaşmaları ile farklı değişkenler (mesleki doyum, mesleki benlik saygısı ve okul iklimi vb.) arasındaki ilişki incelenebilir. Bununla birlikte nitel araştırma çerçevesinde yapılacak görüşmeler ile bu konuda daha ayrıntılı bilgilere ulaşılabilir. Bu araştırma sadece devlet okullarında görev yapan psikolojik danışmanlar ile gerçekleştirilmiştir. Bu araştırmanın bir sınırlılı̆ıdır. Ileride yapılacak araştırmalarda özel kuruluşlarda görev yapan psikolojik danışmanlar ile çalışılabilir. Ayrıca psikolojik danışmanların yabancılaşmalarının incelenmesinde yöneticiler, öğretmenler ve öğrencilerin görüşleri de alınarak daha kapsamlı sonuçlara varılabilir. Psikolojik danışmanların yabancılaşma yaşamamaları için öz yeterliklerini arttırıcı ve tükenmişliklerini azaltıcı teorik ve pratik içerikli eğitimler gerçekleştirilebilir. Bireysel ve mesleki gelişime katkı sağlayacak olan bu eğitimler psikolojik danışmanlar için olabileceği gibi yönetici ve öğretmenlere yönelik de olabilir. Bu sayede psikolojik danışmanların yaşadıkları yabancılaşmaya ilişkin farkındalıkları artırılabilir. Bununla birlikte psikolojik danışmanların daha az yabancılaşma yaşamalarına yönelik olarak, okullarda işbirliğine dayalı bir iklimin oluşturulması ve dayanışma esaslı bir kültürün sağlanması önerilmektedir. 


\section{KAYNAKLAR}

Aksoy, V. ve Diken, I. H. (2009). Rehber öğretmenlerin özel eğitimde psikolojik danışma ve rehberliğe ilişkin öz yeterlik algılarının incelenmesi. IIlköğretim Online, 8(3), 709-719.

Akten, S. (2007). Rehber öğretmenlerin meslekî tükenmişlik düzeylerinin incelenmesi. (Yayınlanmamış Yüksek Lisans Tezi). Trakya Üniversitesi, Ankara.

Al-Darmaki, F. R. (2005). Counseling self-efficacy and Its relationship to anxiety and problemsolving in United Arab Emirates. International Journal for The Advancement of Counselling. 27(2), 323-335.

Asarlı, Z. (2012). Okullarda çalışan psikolojik danışmanların okul psikolojik danışma özyeterlik algılarının incelenmesi. (Yayınlanmamış Yüksek Lisans Tezi). Ege Üniversitesi, İzmir.

Ataş, Ö. ve Ayık, A. (2013). Öğretmen adaylarında okula yabancılaşma. Electronic Turkish Studies, 8(8), 103-122.

Avcı, M. (2010). Rehber öğretmenlerin eş zamanlı görevlendirme uygulamasına ilişkin görüşleri. (Yayınlanmamış Yüksek Lisans Tezi). Yeditepe Üniversitesi, İstanbul.

Aydemir, S. (2014). Rehber öğretmenlerin yöneticilerinin liderlik tarzını algılamaları ile tükenmişlik düzeyleri arasındaki iliş̧inin incelenmesi. (Yayınlanmamış Yüksek Lisans Tezi). Maltepe Üniverstesi, İstanbul.

Aydın, İ., Arastaman, G. vd. (2011). Türkiye'de ilköğretim okulu yöneticileri ile rehber öğretmenler arasındaki çatışma kaynakları. Eğitim ve Bilim. 36(160), 199-212.

Bandura, A. (1986). Social foundations of thought and action: A social cognitive perspective. Englewood Cliffs, NJ: Princeton-Hall.

Bardhoshi, G., Schweinle, A. vd. (2014). Understanding the Impact of School Factors on School Counselor Burnout: A Mixed-Methods Study. Professional Counselor, 4(5), 426-443.

Başören, M. (2005). Çeşitli değişkenlere göre rehber öğretmenlerin tükenmişlik düzeylerinin incelenmesi (Zonguldak ili örneği). (Yayınlanmamış Yüksek Lisans Tezi). Zonguldak Karaelmas Üniversitesi, Zonguldak.

Belgi, S. (2016). Lisede çalışan rehber öğretmenlerin öz yeterlik algıları ve mesleki tükenmişliklerinin incelenmesi. (Yayınlanmamış Yüksek Lisans Tezi). Nişantaşı Üniversitesi, İstanbul.

Bilgiç, H. S. (2011). Rehber öğretmenlerin (psikolojik danışmanların) öz yeterlilikleri. (Yayınlanmamış Yüksek Lisans Tezi). Selçuk Üniversitesi, Konya.

Bodenhorn, N. and Skaggs, G. (2005). Development of the school counselor selfefficacy scale. Measurement and Evaluation in Counseling and Development, 38, 14-29.

Boz, M. (2014) Eğitim örgütlerinde işe yabancılaşma ve öfke ilişkisi. (Yayınlanmamış Yüksek Lisans Tezi). Bahçeşehir Üniversitesi, İstanbul.

Butler, J. (2005). Giving on account of oneself. Oxford University Press.

Büyüköztürk, Ş. (2009). Sosyal bilimler için veri analizi el kitabı. Ankara: Pegem A Yayıncılık.

Camadan, F., Kahveci G. vd. (2016). Rehber öğretmenlerde (psikolojik danışmanlarda) yabancılaşma nitel bir araştırma. IV. Uluslararası Eğitimde Araştırma Kongresi. Recep Tayip Erdoğan Üniversitesi, 13-15 Ekim, Rize. 
Cheng, S., Liu, G., et al. (2011). Primary and secondary school counseling staff self-efficacy relevant factors. Psychology. 2(3), 226-229.

Çağlar, Ç. (2013). Eğitim fakültesi öğrencilerinin yabancılaşma düzeyleri ile öğretmenlik mesleğine yönelik tutumları arasındaki ilişki. Kuram ve Uygulamada Eğitim Bilimleri, 13(3), 1497-1513.

Çapri, B. (2013). Tükenmişlik ölçeği-kısa formu ile eş tükenmişlik ölçeği-kısa formu’nun Türkçe uyarlaması ve Psikoanalitik-Varoluşçu bakış açısından mesleki ve eş tükenmişlik ilişkisi. Kuram ve Uygulamada Eğitim Bilimleri,13(3), 1393-1418

Çınar, Y. (2016). Psikolojik danışmanların tükenmişlik düzeyleri ve problem çözme becerilerinin incelenmesi. (Yayınlanmamış Yüksek Lisans Tezi). Gazi Üniversitesi, Ankara.

Çokluk, Ö., Şekercioğlu, G. vd. (2012). Sosyal bilimler için çok değişkenli SPSS ve LISREL uygulamaları. Ankara: Pegem A Yayıncılık.

Elma, C. (2003). Illköğretim okulu öğretmenlerinin işe yabancılaşması (Ankara ili örneği). (Yayınlanmamış Doktora Tezi). Ankara Üniversitesi, Ankara.

Erkan Atik, Z. (2011). Okul psikolojik danışmanı öz yeterliğini yordamada eğitim yaşantılarına ilişkin memnuniyetin rolü. (Yayınlanmamış Yüksek Lisans Tezi). Uludağ Üniversitesi, Bursa.

Eryılmaz, A. (2010). Lise öğretmenlerinin örgütsel yabancılaşma düzeyi. (Yayınlanmamış Yüksek Lisans Tezi). Hacettepe Üniversitesi, Ankara.

Fayda Kınık, Ş. F. (2010). Öğretmenlerin yabancılaşma algıları. (Yayınlanmamış Yüksek Lisans Tezi). Yıldız Teknik Üniversitesi, İstanbul.

Freudenberger, H. J. (1974). Staff burn-out. Journal of social issues, 30(1), 159-165.

Gündüz, B. ve Çelikkaleli, Ö. (2009). Okul psikolojik danışmanlarında mesleki yetkinlik inancı. Mersin Üniversitesi Eğitim Fakültesi Dergisi, 5(1), 119-133.

Güven, M. (2009). Milli Eğitim Bakanlığı müfettişlerinin okul rehberlik hizmetleri ve denetimiyle ilgili görüşleri. Uluslararası Sosyal Araştırmalar Dergisi. 2(9), 171-179.

Hatunoğlu, Y. ve Hatunoğlu, Y. (2006). Okullarda verilen rehberlik hizmetlerinin problem alanları. Kastamonu Eğitim Dergisi, 14(1), 333-338

Işıksal, M. ve Aşkar, P. (2003). Ilköğretim öğrencileri için matematik ve bilgisayar öz-yeterlik algısı ölçekleri. Hacettepe Üniversitesi Eğitim Fakültesi Dergisi, 25(25), 109-118.

İkiz, F. E. (2010). Psikolojik danışmanlarının tükenmişlik düzeylerinin incelenmesi. Ahi Evran Üniversitesi Eğitim Fakültesi Dergisi, 2(11) , 25-43

Jaeggi, R. (2014). Alienation. Columbia University Press.

Karasar, N. (2016). Bilimsel araştırma yöntemi. Ankara: Nobel Yayınları.

Karataş, Z. ve Baltacı, H. Ş. (2013). Ortaöğretim kurumlarında yürütülen psikolojik danışma ve rehberlik hizmetlerine yönelik okul müdürü, sınıf rehber öğretmeni, öğrenci ve okul rehber öğretmeninin (psikolojik danışman) görüşlerinin incelenmesi. Ahi Evran Üniversitesi Kırşehir Eğitim Fakültesi Dergisi, 14(2), 427-460.

Kasapoğlu, S. (2015). Illköğretim okulu öğretmenlerinin işe yabancılaşma düzeyleri ile örgütsel adalet algıları arasındaki ilişki. (Yayınlanmamış Yüksek Lisans Tezi). Yıldız Teknik Üniversitesi, İstanbul. 
Kaya, T. (2009). Rehber öğretmenlerin tükenmişlik düzeylerinin çeşitli değişkenlere göre incelenmesi. (Yayınlanmamış Yüksek Lisans Tezi). Beykent Üniversitesi, İstanbul.

Kesik, F. ve Cömert, M. (2014). Illköğretim okullarında görev yapan öğretmenlerin işe yabancılaşma düzeylerine ilişkin algıları. Inönü Üniversitesi Eğitim Fakültesi Dergisi, 15(1), 27-46.

Kızıl, D. (2007). Ortaöğretim kurumlarındaki rehber öğretmenlerin ve sınıf rehber öğretmenlerin sınıf içi rehberlik etkinlikleri ile ilgili görüşleri. (Yayınlanmamış Yüksek Lisans Tezi). Selçuk Üniversitesi, Konya.

Kline, R. B. (2015). Principles and practice of structural equation modeling. New York: Guilford Press.

Larson, L. M. and Daniels, J. A. (1998). Review of the counseling self-efficacy literature. The Counseling Psychologist, 26, 179-218.

Maslach, C. (1982). Burnout: The cost of caring. ISHK.

Maslach, C. and Goldberg, J. (1998). Prevention of burnout: New perspectives. Applied And Preventive Psychology, 7(1), 63-74.

Maslach, C., Schaufeli, W. B. vd. (2001). Job burnout. Annual Review of Psychology, 52(1), 397422.

Melchert, T. P., Hays, V. L. vd. (1996). Testing models of counselor development with a measure of counseling self-efficacy. Journal of Counseling \& Development, 74(6), 640644.

Moyer, M. (2011). Effects of non-guidance activities, supervision, and student-to-counselor ratios on school counselor burnout. Journal of School Counseling, 9(5), 1-31.

Owens, D., Bodenhorn, N. vd. (2010). Self-efficacy and multicultural competence of school counselors. Journal of School Counseling, 8(17), 1-20.

Özçınar, M. (2011). Örgütlerde yabancılaşma ile tükenmişlik sendromu arasındaki ilişkiyi belirlemeye yönelik bir araştırma. (Yayınlanmamış Yüksek Lisans Tezi). Dumlupınar Üniversitesi, Kütahya.

Özgözgü, S., Bektaş, M., vd. (2017). Okul psikolojik danışmanlarının genel öz-yeterlik inançları ve örgütsel özdeşleşme algıları. Illköğretim Online. 16(3), 1058-1078.

Öztürk, T. (2014). Psikolojik danışman ve sınıf rehber öğretmenlerinin ilköğretim okullarındaki pdr servislerine ilişkin etkililik algılamalarının bazı değişkenler açısından incelenmesi. (Yayınlanmamış Yüksek Lisans Tezi). Çukurova Üniversitesi, Adana.

Pajares, F. (1996). Self-efficacy beliefs in academic settings. Review of Educational Research, 66(4), 543-578.

Pallant, J. (2015). SPSS kullanma kılavuzu (Çev. Sibel, Balcı ve Berat, Ahi.). Ankara: Nobel Yayınları.

Pines, A. M. (2005). The burnout measure short version (BMS). International Journal of Stress Management, 12, 78-88.

Seeman, M. (1959). On The Meaning of Alienation. American Sociological Review, 24(6),783791. 
Stickel, S. A. (1991, Feb). A study of burnout and job satisfaction among rural school counselors. Annual Conference of the Eastern Educational Research Association, Boston, MA.

Tabachnick, B. G. ve Fidell, L. F. (2015). Çok değişkenli istatistiklerin kullanımı. (Çev. Mustafa Baloğlu). Ankara: Nobel Yayınları.

Temel,C., Mirzeoglu, N. vd. (2013). An investigation of physical education teachers' work alienation level according to some variables. International Journal of Academic Research, 5(4), 513-519.

Umay, G. (2015). Psikolojik danışman ve rehberlik öğretmenlerinin iş doyumu ve tükenmişlik düzeylerinin ilişkisi. (Yayımlanmamış Yüksek Lisans Tezi). Yeditepe Üniversitesi, İstanbul.

Wachter, C. A., Clemens, E. V. vd. (2008). Exploring school counselor involvement of student stakeholders and school counselor burnout through an Adlerian theoretical framework. Journal of Individual Psychology, 64(4), 432-449.

Worzbyt, J. C., O'Rourke, K. et al. (2003). Elementary school counseling: a commitment to caring and community building. Brunner-Routledge: New York.

Yıldız, E. (2012). Eğitimcilerde tükenmişlik (rehber öğretmenler üzerinde bir araştırma). (Yayınlanmamış Yüksek Lisans Tezi). Sakarya Üniversitesi, Sakarya. 


\section{SUMMARY}

In the related literature, there are studies showing that alienation is also seen among psychological counselors. It is therefore thought that it is important that the psychological counselors deal with this situation in detail and determine its reasons. In the related area review of literature, selfefficacy and burnout have also been found to have an impact on the performance of individuals in the workplace. It is estimated that the variables mentioned in this context may also have an effect on alienation. When the researchers on this subject were examined, it was found that there were no studies that examined alienation, self-efficacy, and burnout together. Therefore, it is evaluated that this research will contribute to body of literature in this direction. It is also envisaged that the outcomes of the alienation of psychological counselors will give the psychological counselors an insight into the development and improvement of work life. However, it is seen that the variables of this research have whether or differentiation in terms of various demographic variables such as age, gender, level of education, working school type and working teaching step. In the context of this research, it is thought that the research variables are important to examine the differentiation situation in terms of gender, working teaching step (primary, secondary and high school) and age variables, which are widely considered to be investigated. In the context of these explanations, the purpose of the study was to examine the role of self-efficacy and burnout on the alienation of psychological counselors.

The model of this research carried out within the framework of quantitative research approach is relational scanning. The research was conducted with 203 psychological counselors working in Trabzon, Rize and Artvin provinces and district in 2016-2017 academic years. 134 of the participants were female (66.00\%) and 69 were male (34.00\%). In the scope of this research, The School Counselors Self-Efficacy Scale, Burnout Measure-Short Version, Organizational Scale of Alienation and Personal Information Form were used to collect data. An examination of the role of self-efficacy and burnout on the alienation of psychological counselors, which is the aim of the research, was performed by multiple regression analysis. Comparison of in term of gender with t-test, comparison of working teaching step and age with ANOVA was realized.

It has been determined that there is a moderate relationship between the alienation and selfefficacy of psychological counselors in the negative $(r=-.41)$, as well as a moderate relationship $(r=-.33)$ in the same way when the effect of burnout is controlled. It was also found that there was a moderate relationship between alienation and burnout $(r=.66)$ in the positive direction and a moderate relationship ( $r=.63$ ) between the two variables in the positive direction when the effect of this selfefficacy was controlled. It is seen that the psychological counselors, together with the alienation of selfefficacy and burnout, and associated at a high level positively, and that the variables mentioned explain $50 \%$ of the alienation and the model created are significant $\left(R=.71, F_{(2-200)}=99.759, p<.001\right)$. According to the standardized regression coefficient $[\beta]$, it is understood that the order of significance on the alienation of the predictor variables is in the way burnout and self-efficacy. In addition, when the calculated t-test results for the significance of the regression coefficients are examined, it is seen that burnout $(\beta=.594, p<.001)$ and self-efficacy $(\beta=-.254, p<.001)$ are significantly explained to alienation. In the research, it was understood that psychological counselors did not differ significantly in their alienation $\left(t_{201}=1.517, p>0.05\right)$ and self-efficacy $\left(t_{201}=-1.110, p>0.05\right)$ compared to gender. However, it has been determined that the burnout of psychological counselors varies significantly according to gender $\left(t_{201}=2.425, p<0.05\right)$, and female have more burnout $($ ? $=2.90)$ than male $($ ? $=2.55)$. Psychological counselors found that alienation $\left(F_{2-200}=.157, p>0.05\right)$, self-efficacy $\left(F_{2-200}=1.511, p>0.05\right)$ and burnout $\left(F_{2-200}=1.806, p>0.05\right)$ did not significantly differ according to working teaching step. Moreover, it was determined that the alienation $\left(F_{3-199}=.680, p>0.05\right)$, self-efficacy $\left(F_{3-199}=.858, p>0.05\right)$, and burnout $\left(F_{3-}\right.$ $\left.{ }_{199}=1.323, p>0.05\right)$ of psychological counselors did not significantly differ according to age.

In the future research, the relationship between the alienations of psychological counselors and different variables (occupational satisfaction, professional self-esteem, and school climate etc.) can be examined. However, more detailed information can be reached on this issue with the negotiations to be carried out under qualitative research. In addition, in the examination of the alienation of psychological counselors, more comprehensive results can be obtained by taking the opinions of administrators, teachers, and students. 